\title{
Spatial and seasonal contrasts of sedimentary organic matter in floodplain lakes of the central Amazon basin
}

\author{
R. L. Sobrinho ${ }^{1,2}$, M. C. Bernardes ${ }^{1}$, G. Abril ${ }^{1,3}$, J.-H. Kim ${ }^{2,4}$, C. I Zell ${ }^{2}$, J.-M. Mortillaro ${ }^{5}$, T. Meziane ${ }^{5}$, \\ P. Moreira-Turcq ${ }^{6}$, and J. S. Sinninghe Damstét ${ }^{2,7}$ \\ ${ }^{1}$ Universidade Federal Fluminense, Department of Geochemistry, 24020-141, Niteroi, Rio de Janeiro, Brazil \\ ${ }^{2}$ NIOZ Royal Netherlands Institute for Sea Research, Department of Marine Organic Biogeochemistry, P.O. Box 59, \\ 1790 AB Den Burg, Texel, the Netherlands \\ ${ }^{3}$ Laboratoire EPOC, Université Bordeaux 1, CNRS UMR-5805, Avenue des Facultés, 33405 Talence, France \\ ${ }^{4}$ Department of Marine Science and Convergence Technology, Hanyang University ERICA campus, 55 Hanyangdaehak-ro, \\ Sangnok-gu, Ansan-si, Gyeonggi-do 426-791, South Korea \\ ${ }^{5}$ UMR-CNRS-IRD-UPMC 7208, BOREA, Département Milieux et Peuplements Aquatiques, MNHN, CP 53, \\ 61 rue Buffon, 75231 Paris CEDEX 05, France \\ ${ }^{6}$ IRD (Institut de Recherche pour le Développement) GET (Géosciences Environnement Toulouse), \\ Casilla 18-1209, Lima 18, Peru \\ ${ }^{7}$ Utrecht University, Faculty of Geosciences, P.O. Box 80.021, 3508 TA Utrecht, the Netherlands
}

Correspondence to: R. L. Sobrinho (rsobrinho@nioz.nl)

Received: 8 May 2015 - Published in Biogeosciences Discuss.: 15 June 2015

Revised: 13 December 2015 - Accepted: 25 December 2015 - Published: 22 January 2016

\begin{abstract}
In this study, we investigated the seasonal and spatial pattern of sedimentary organic matter (SOM) in five floodplain lakes of the central Amazon basin (Cabaliana, Janauaca, Canaçari, Mirituba and Curuai) which have different morphologies, hydrodynamics and vegetation coverages. Surface sediments were collected in four hydrological seasons: low water (LW), rising water (RW), high water (HW) and falling water (FW) in 2009 and 2010. We investigated commonly used bulk geochemical tracers such as the $\mathrm{C}: \mathrm{N}$ ratio and the stable isotopic composition of organic carbon $\left(\delta^{13} \mathrm{C}_{\text {org }}\right)$. These results were compared with lignin phenol parameters as an indicator of vascular plant detritus and branched glycerol dialkyl glycerol tetraethers (brGDGTs) to trace the input of soil organic matter (OM) from land to the aquatic settings. We also applied the crenarchaeol as an indicator of aquatic (rivers and lakes) OM. Our data showed that during the RW and FW seasons, the surface sediments were enriched in lignin and brGDGTs in comparison to other seasons. Our study also indicated that floodplain lake sediments primarily consisted of allochthonous, $\mathrm{C}_{3}$ plant-derived OM. However, a downstream increase in $\mathrm{C}_{4}$ macrophyte-derived OM contribution was observed along the gradient of increas-
\end{abstract}

ing open waters - i.e., from upstream to downstream. Accordingly, we attribute the temporal and spatial difference in SOM composition to the hydrological dynamics between the floodplain lakes and the surrounding flooded forests.

\section{Introduction}

Inland waters play a significant role in the global carbon budget. Lakes and rivers are active systems where the transport, transformation and storage of organic carbon (OC) affect the carbon cycle on a landscape and global scale (e.g., Cole et al., 2007; Tranvik et al., 2009; Raymond et al., 2013). In this context, the wetlands are dynamic interfaces between the terrestrial and aquatic realms, which promote the redistribution of carbon sources and sinks. Thus, they must be taken into account for the carbon fluxes and storage in the continents and for climate change mitigation strategies (Battin et al., 2009). Floodplain lakes are temporary or permanent water bodies formed in the wetlands of the Amazon basin. They are among the most productive ecosystems in the world (Junk, 1997; Melack and Forsberg, 2001). The primary production is per- 
formed by the flooded forests, macrophytes, phytoplankton, and periphyton (Junk et al., 2010). Inputs of $\mathrm{CO}_{2}$ from plant respiration and reactive $\mathrm{OC}$ produced in floodplain lakes are significant sources of $\mathrm{CO}_{2}$ outgassed in the central Amazon basin (Abril et al., 2014). The periodic floods intensify the exchange of organic compounds, nutrients and minerals between rivers, lakes and flooded soils (Junk, 1997). Although only $10-20 \%$ of the organic matter (OM) produced in the water column reaches the sediment and is finally buried (Devol et al., 1984), the sediments in these lakes are important sinks of carbon (Moreira-Turcq et al., 2004). Most of the sedimentary organic matter (SOM) in freshwater systems is derived from terrestrial vascular plants (Goñi and Hedges, 1992; Moreira-Turcq et al., 2004; Mortillaro et al., 2011). In the Amazon basin, many studies have characterized the suspended particulate organic matter (SPOM) in the rivers and the floodplain lakes and concluded that the main sources of $\mathrm{OM}$ to the aquatic system are the forests and the upstream Andean soils (e.g., Hedges et al., 1986, 1994; Quay et al., 1992; Victoria et al., 1992; Moreira-Turcq et al., 2004, 2013; Aufdenkampe et al., 2007; Mortillaro et al., 2011; Zell et al., 2013b). However, little is known about the molecular composition of the SOM in the floodplain lakes in general, and in particular, the contribution of the multiple sources of OM (upland soils, flooded and non-flooded forests, aquatic macrophytes, and phytoplankton) remains uncertain (Mortillaro et al., 2011; Zocatelli et al., 2011; Moreira et al., 2014).

The seasonality and the spatiality of the wetlands in the Amazon basin strongly influence the dynamics and the quality of OM in the surface sediments of floodplain lakes. Most of the SOM is supposed to be transported to the floodplain lakes via Amazon River main stem during the rising and high water seasons (Hedges et al., 1986; Victoria et al., 1992; Moreira-Turcq et al., 2004, 2013; Mortillaro et al., 2011). However, a significant increase in the vertical flux of $\mathrm{OM}$ was observed in Lake Curuai during the falling water season, which is interpreted as the result of resuspended sediments when the lake becomes smaller and shallower (MoreiraTurcq et al., 2004). In terms of the spatiality, the downstream lakes present higher values of $\delta^{13} \mathrm{C}_{\text {org }}$ in comparison to the upstream lakes (Victoria et al., 1992). This variability may be explained by the differences in the interfaces between the rivers and the lakes along the upstream-downstream transect or in aquatic primary production (mainly aquatic plants), which is more widespread in the open water lakes downstream. A previous study of bulk parameters and fatty acids in the central Amazon basin (Mortillaro et al., 2011) was not conclusive about the sources of SOM in floodplain lakes. Hence, the present work applies multiple biomarkers, namely lignin phenols, branched glycerol dialkyl glycerol tetraethers (brGDGTs) and crenarchaeol (isoprenoid GDGT), in addition to the bulk parameters, to disentangle the sources of SOM in floodplain lakes of the central Amazon basin and the role of the spatiality and seasonality in determining the composition of the SOM.

Lignin is produced by vascular plants. It is composed of phenolic compounds and is generally considered as a recalcitrant organic molecule. As a consequence, the products of $\mathrm{CuO}$ degradation of lignin (Hedges and Ertel, 1982) have been widely applied as biomarkers to trace plant material to aquatic systems (Hedges et al., 1986; Bernardes et al., 2004; Aufdenkampe et al., 2007; Kuzyk et al., 2008). Previous works in the Amazon basin showed that lignin is an important component of fossil OC in floodplain lakes (Zocatelli et al., 2013) but also a relevant carbon source for the outgassing of $\mathrm{CO}_{2}$ in the Amazon River (Ward et al., 2013). This apparent contradiction reflects the relevance of environmental conditions on the degradation of organic molecules (Schmidt et al., 2012) which must be considered in the application of these biomarkers. The GDGTs are membrane lipids mainly composed of acyclic or cyclic biphytane core lipids with two glycerol head groups (Hopmans et al., 2000). The head groups are easily degraded while the two biphytanyl core lipids are well preserved in sediments and soils (White et al., 1979; Harvey et al., 1986). The GDGTs are found in diverse environments worldwide but the brGDGTs are mainly produced in the soil (by the bacteria domain e.g., Weijers et al., 2006), and the crenarchaeol is predominant in the aquatic environments and produced by Thaumarchaeota (Sinninghe Damsté et al., 2002). Accordingly, the relative amount of brGDGTs to the crenarchaeol, the so-called Branched and Isoprenoid Tetraether (BIT) index, have been proposed to quantify the OC proportion originating from soils and aquatic environments (e.g., Hopmans et al., 2004; Herfort et al., 2006; Belicka and Harvey, 2009; Smith et al., 2010). Previously, this method was successfully applied in rivers and floodplain lakes of the Amazon basin (e.g., Kim et al., 2012; Zell et al., 2013a; Moreira et al., 2014). A comparison between lignin phenols and GDGTs as markers for terrestrial OC has been performed in marine and lacustrine systems (e.g., Smith et al., 2010). This comparison showed complementary information on the transport and sedimentation of terrestrial OC in aquatic systems. Finally, the combination of these two groups of biomarkers with the bulk parameters, analyzed in superficial sediments collected in five floodplain lakes of the central Amazon basin in four hydrological seasons, provides new insights into the link between the hydrology of the Amazon basin to the sources of SOM in floodplain lakes.

\section{Study area}

The Amazon River is the world's largest river with a drainage basin area of $6.1 \times 10^{6} \mathrm{~km}^{2}$ covering about $40 \%$ of South America (Goulding et al., 2003). The mean annual discharge is $200 \times 10^{3} \mathrm{~m}^{3} \mathrm{~s}^{-1}$ at Óbidos, the most downstream gauging station on the Amazon River (Callede et al., 2010). Rivers within the Amazon drainage basin are traditionally classified 


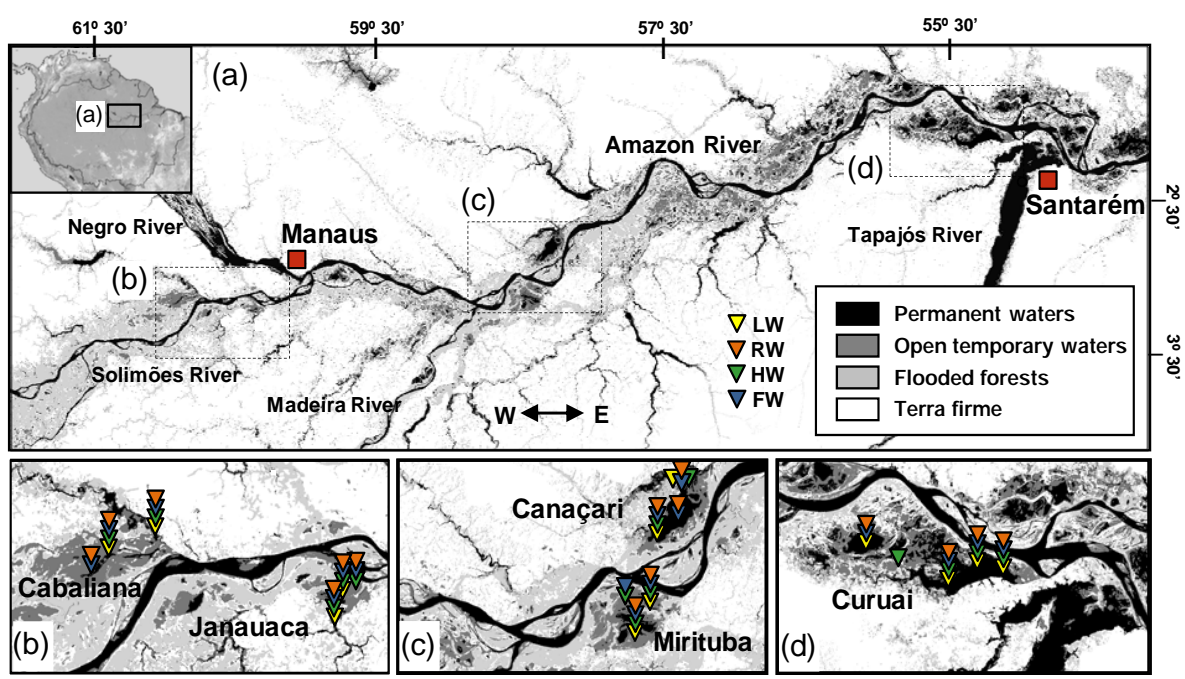

Figure 1. Study area of the central Amazon basin (a) showing five floodplain lakes (várzeas) in panels (b, c, d).

Table 1. Localization and summary of geomorphology, biogeography, and water physicochemical of the five floodplain lakes. Data of temperature, conductivity and $\mathrm{pH}$ represent the maximum and minimum values measured in situ for four hydrological seasons.

\begin{tabular}{llllll}
\hline & Cabaliana & Janauaca & Mirituba & Canaçari & Curuai \\
\hline Latitude $(\mathrm{S})$ & $3^{\circ} 18^{\prime} 46^{\prime \prime}$ & $3^{\circ} 23^{\prime} 20^{\prime \prime}$ & $3^{\circ} 20^{\prime} 50^{\prime \prime}$ & $2^{\circ} 58^{\prime} 60^{\prime \prime}$ & $2^{\circ} 09^{\prime} 44^{\prime \prime}$ \\
Longitude $(\mathrm{W})$ & $60^{\circ} 40^{\prime} 15^{\prime \prime}$ & $60^{\circ} 16^{\prime} 26^{\prime \prime}$ & $58^{\circ} 23^{\prime} 60^{\prime \prime}$ & $58^{\circ} 15^{\prime} 40^{\prime \prime}$ & $55^{\circ} 27^{\prime} 53^{\prime \prime}$ \\
Approx. area $\left(\mathrm{km}^{2}\right)$ & 300 & 85 & 360 & 290 & 1050 \\
Shape & Ellipsoid & Ravine dendritic & Round & Ellipsoid & Triangular \\
Wetland vegetation type & Forests & Forests & Forests/Woodlands & Forests/Woodlands & Woodlands/Shrubs \\
Water & White/Black & White/Clear & White & White/Black & White \\
Conductivity $(\mu \mathrm{S})$ & $10-80$ & $33-71$ & $43-65$ & $10-54$ & $41-69$ \\
Temperature $\left({ }^{\circ} \mathrm{C}\right)$ & $28-34$ & $29-33$ & $28-34$ & $29-34$ & $30-36$ \\
pH & $5.0-7.5$ & $6.1-8.0$ & $6.2-8.5$ & $5.9-9.4$ & $7.3-10.1$ \\
\hline
\end{tabular}

Obs.: All várzeas receive white water from the Solimões-Amazon River in the flooding season.

according to water color, as well as physical and chemical parameters (Sioli, 1950): white water (e.g., Solimões, Madeira and Amazon rivers), black water (e.g., Negro River), and clear water (e.g., Tapajós River). The total area of wetland is $350 \times 10^{3} \mathrm{~km}^{2}$ (Melack and Hess, 2011). $17 \%$ of the central Amazon basin is subjected to periodic floods. This creates large temporary wetlands - i.e., seasonally flooded forests, woodlands, and shrubs - corresponding to $58 \%$ of the total flooded area during the high water season. Aquatic macrophytes, floating meadow and marsh cover 5 to $8 \%$ of the wetlands, and open waters correspond to 12 and $14 \%$ in low and high water seasons, respectively (Hess et al., 2003).

Five floodplain lakes were investigated in this study: Cabaliana, Janauaca, Mirituba, Canaçari and Curuai (Fig. 1a, Table 1). The lakes are located along the Solimões-Amazon River shoreline in a biogeographic gradient of upstream flooded forests to downstream flooded woodlands and open water lakes (Bourgoin et al., 2007; Abril et al., 2014). Cabaliana is a round-shaped lake surrounded by flooded forests and two sub-regions (Fig. 1b). In the northern region, the Manacapuru River discharges black water while in the southern region, the white water brought by the Solimões River, mixes with black water. Janauaca has a peculiar morphology with a ravine shape surrounded by flooded forests (Fig. 1b). Solimões water comes through the channel in the north, and some clear water comes through the stream system in the south. Conductivity values in lakes Cabalina and Janauaca are close to that of the Solimões River, evidencing that white waters predominate. Mirituba has a round shape and receives white water from the Madeira River and the Amazon River through a complex drainage system (Fig. 1c). It is a white water lake surrounded by flooded forests and woodlands, with no significant contribution of black water streams. Canaçari has two well-defined sub-regions (Fig. 1c). In the northern region, the Urubu River discharges black water and in the southern region, the Amazon River discharges white water. It is surrounded by flooded forests and woodlands and the conductivity is close to that of the white waters of the Amazon 
River. Curuai is the largest lake in the central Amazon basin, mainly surrounded by woodlands and open waters (Fig. 1d). It receives in majority white water from the Amazon River through channels connected to the main stem. Small contributions of black water streams occur in the Curuai floodplain, but remain spatially restricted to their most Southeastern region.

\section{Materials and methods}

\subsection{Sample collection}

Surface $(0-2 \mathrm{~cm})$ sediment samples $(n=57)$ were collected using a grab sampler of $100 \mathrm{~cm}^{3}$ in lakes Cabaliana, Janauaca, Mirituba, Canaçari and Curuai in the central Amazon basin between Manaus and Santarém (Fig. 1). The four hydrological seasons were targeted during different research cruises with a small vessel (Fig. 2): in June and July 2009, which covered the high water (HW) season; in October 2009 the low water (LW) season, in August 2010 the falling water (FW) season and in January 2011 the rising water (RW) season. In each floodplain lake, sediment samples were collected at three stations in each season. However, sometimes only two samples were collected when stations were not accessible during a specific season. Thus, approximately 12 samples in each lake and 15 samples per season were obtained. The samples were collected in the three most distinct sites of each lake: near the connecting channel, in the middle of the lake and near the flooded forests. Most of the sampling sites were located in areas flooded by the Solimões-Amazon River water (white water). In Cabaliana and Canaçari one station was located near the black water streams in order to represent the heterogeneity of the lakes.

Four wetland soils and three nonfloodable soils from well above the maximum inundations levels, known as "terra firme", were also collected during the LW season. In addition, four samples of $\mathrm{C}_{3}$ (Eichornia sp., Pistia stratiotes) and $\mathrm{C}_{4}$ (Paspalum repens) aquatic plants (macrophytes) were sampled during the $\mathrm{HW}$ season in the lakes Janauaca and $\mathrm{Cu}-$ ruai. All samples were kept frozen $\left(-20^{\circ} \mathrm{C}\right)$ on the ship and transported frozen to the Universidade Federal Fluminense laboratory (Brazil), where they were freeze-dried.

\subsection{Bulk geochemical parameters}

For the samples collected during the HW and LW seasons, total carbon (TC), total nitrogen (TN) and $\delta^{13} \mathrm{C}$ of TC were determined at the Davis Stable Isotope Facility (Department of Plant Sciences, University of California at Davis, California, USA) using a Europe Hydra 20-20 mass spectrometer equipped with a continuous flow isotope ratio monitoring device. Other samples gathered during the FW and RW cruises were analyzed for TC, TN, and $\delta^{13} \mathrm{C}$ of TC using a Flash 2000 organic elemental analyzer interfaced with a Delta $\mathrm{V}$ advantage isotope ratio mass spectrometer at the

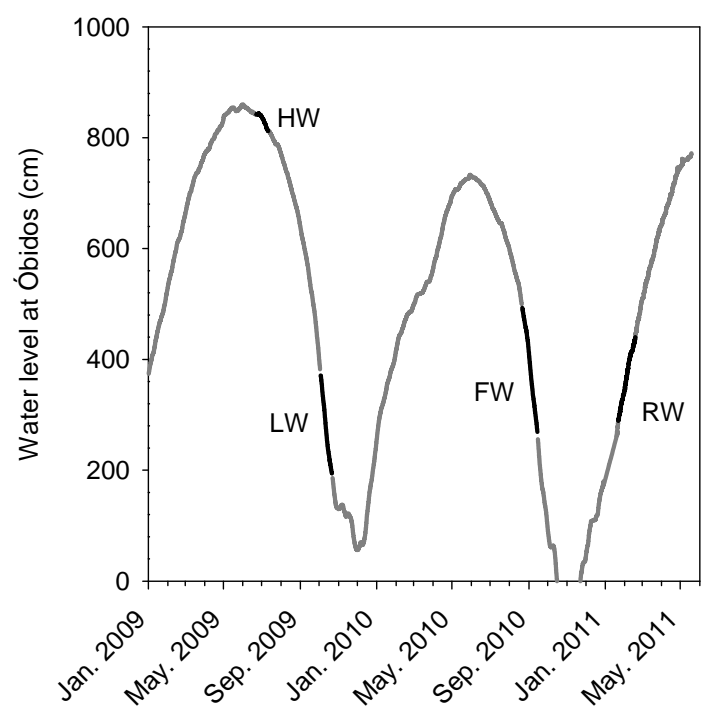

Figure 2. Seasonal water level changes of the Amazon River main stem at the town Óbidos $(\mathrm{RW}=$ rising water, $\mathrm{HW}=$ high water, $\mathrm{FW}=$ falling water, $\mathrm{LW}=$ low water).

Royal Netherlands Institute for Sea Research (NIOZ, the Netherlands). The average precision was $\pm 0.1 \mathrm{mg} \mathrm{Cg}^{-1}$ for $\mathrm{TC}$ and $\pm 0.05 \mathrm{mg} \mathrm{N} \mathrm{g}^{-1}$ for TN. In addition, 16 decarbonated sediment samples were analyzed for the total organic carbon (TOC) contents at NIOZ and at Universidade Federal Fluminense (UFF) using a Carlos Erba elemental analyzer EA 1110. These analyses were determined in duplicate with a precision of $0.1 \mathrm{mg} \mathrm{Cg}^{-1}$. TC (wt. \%) correlated very well with TOC (wt. \%) with an intercept not significantly different from $0\left(R^{2}=0.96, p<0.001, n=16\right)$. This indicates that TC in the floodplain lakes' sediments investigated was predominantly TOC and the fraction of carbonates was minor. Therefore, TC was considered as TOC in this study. In order to assess the contribution of inorganic nitrogen $\left(\mathrm{NH}^{+4}+\mathrm{NO}^{-2}+\mathrm{NO}^{-3}\right)$ to $\mathrm{TN}$, TN (wt. \%) and TOC (wt. \%) were correlated $\left(R^{2}=0.89 ; p<0.001 ; n=16\right)$. The interception of the correlation line on the TN axis (0.06) was interpreted as the percentage of inorganic nitrogen, suggesting that a contribution of mineral nitrogen present in finegrained sediments accounted for ca. $0.06 \mathrm{wt}$. \%. We thus subtracted 0.06 wt. $\%$ from the TN content and used this for the calculation of the $\mathrm{C}: \mathrm{N}$ ratio. The $\delta^{13} \mathrm{C}$ values of TC are also considered as $\delta^{13} \mathrm{C}$ of TOC $\left(\delta^{13} \mathrm{C}_{\text {org }}\right)$ in this study and reported in the standard delta notation relative to Vienna Pee Dee Belemnite (VPDB) standard. The analytical precision (as the standard deviation for repeated measurements of the internal standards) was $\pm 0.06 \%$ for $\delta^{13} \mathrm{C}_{\text {org }}$.

\subsection{Lignin phenol analysis}

The lignin phenols were extracted from approximately $500 \mathrm{mg}$ lake sediment and soil samples and from $50 \mathrm{mg}$ of macrophyte samples. The samples were freeze-dried and 
the extraction method applied was the alkaline $\mathrm{CuO}$ oxidation (Hedges and Ertel, 1982; Goni and Hedges, 1992) at the Universidade Federal Fluminense laboratory (Brazil). In brief, sediments or macrophytes were transferred to stainless steel reaction vials and digested with $300 \mathrm{mg} \mathrm{CuO}$ in $2 \mathrm{~N}$ $\mathrm{NaOH}$ under $\mathrm{N}_{2}$ in an oxygen-free atmosphere at $150^{\circ} \mathrm{C}$ for $150 \mathrm{~min}$. The samples were acidified to $\mathrm{pH} \mathrm{1-3}$ and subsequently $6 \mathrm{~mL}$ of ethyl acetate was added. After centrifuging at $2500 \mathrm{rpm}$ for $5 \mathrm{~min}$, the supernatant was collected, dried over sodium sulfate $\left(\mathrm{Na}_{2} \mathrm{SO}_{4}\right)$, evaporated under a stream of $\mathrm{N}_{2}$, reconstituted in pyridine, and converted to trimethylsilyl derivatives using bis-(trimethylsilyl) trifluoroacetamide (BSTFA) at $60^{\circ} \mathrm{C}$ for $20 \mathrm{~min}$. Oxidation products were analyzed using an HP Agilent 6890N Series gas chromatography (e.g., Zocatelli et al., 2013).

The recovery factor was calculated using the internal standard ethyl vanillin added after the $\mathrm{CuO}$ oxidation and prior to analysis (values above $60 \%$ were considered). The response factor was performed using a mixture of commercial standards in four different concentrations, which were periodically injected for calibration. To confirm the identification of each lignin phenol, eight selected samples were analyzed with an Agilent 7890A gas chromatograph (GC-FID) coupled to an Agilent 5975C VL MSD mass spectrometer using a selective ion monitoring (SIM) at NIOZ (the Netherlands).

Phenol concentrations were reported as the carbonnormalized sum of eight lignin-derived reaction products ( $\left.\lambda 8 \mathrm{mg} \mathrm{g}_{\mathrm{oc}}^{-1}\right)$, including vanillyl ( $V$-series) phenols (vanillin, acetovanillone, and vanillic acid), syringyl ( $S$-series) phenols (syringaldehyde, acetosyringone and syringic acid), and cinnamyl ( $C$-series) phenols ( $p$-coumaric and ferulic acid). Ratios $S: V$ and $C: V$ were calculated to identify angiosperm tissue sources. The ratio of acidic to aldehyde vanillyl phenols ((Ad: Al) $v)$ was used as an indicator of the lignin degradation state since acidic phenols are produced from aldehyde functional groups during the lignin degradation (Hedges and Ertel, 1982).

\subsection{GDGT analysis}

All samples for the lipid analysis were processed at NIOZ (the Netherlands). The freeze-dried samples were extracted with a modified Bligh and Dyer technique (Bligh and Dyer, 1959; Pitcher et al., 2009). In brief, the samples were extracted three times with a mixture of methanol $(\mathrm{MeOH})$ : dichloromethane (DCM) : phosphate buffer $(8.7 \mathrm{~g}$ of $\mathrm{K}_{2} \mathrm{HPO}_{4}$ in $1 \mathrm{~L}$ bidistilled water) $10: 5: 4(v: v: v)$ in an ultrasonic bath (10 min). Extracts and residues were separated each time by centrifugation at $2500 \mathrm{rpm}$ for $2 \mathrm{~min}$. DCM and phosphate buffer were added to the extracts to give a new volume ratio $1: 1: 0.9(v: v: v)$. This mixture was centrifuged at $2500 \mathrm{rpm}$ for $2 \mathrm{~min}$ to obtain a good phase separation. The DCM phase was then collected in a roundbottomed flask. The $\mathrm{MeOH}-$ phosphate phase was washed twice with DCM and then discarded. The collected DCM fractions were reduced under rotary vacuum.

The Bligh and Dyer extracts were fractioned into core lipids and intact polar lipids (IPLs). The separation was carried out on activated silica with $n$-hexane : ethylacetate $1: 1(v: v)$ for core lipids and $\mathrm{MeOH}$ for IPLs (Pitcher et al., 2009). To each fraction, $0.1 \mu \mathrm{g} \mathrm{C}_{46}$ GDGT internal standard was added (Huguet et al., 2006). Two-thirds of the IPL fraction was hydrolyzed to cleave off polar head groups. The hydrolysis was carried out by refluxing $(3 \mathrm{~h})$ in $2 \mathrm{NHCl}: \mathrm{MeOH} 1: 1(v: v)$. The solution was adjusted to $\mathrm{pH} 5$ with $2 \mathrm{~N} \mathrm{KOH}-\mathrm{MeOH}$. This mixture was washed three times with DCM. The DCM fractions were collected, reduced by rotary evaporation, and dried over a $\mathrm{Na}_{2} \mathrm{SO}_{4}$ column. Core lipids fractions were separated into polar (DCM : MeOH $1: 1, v: v$ ) and apolar (DCM) fraction over an activated $\mathrm{Al}_{2} \mathrm{O}_{3}$ column.

The core lipids and IPL GDGTs were analyzed using high-performance liquid chromatograph-atmospheric pressure positive ion chemical ionization mass spectrometry (HPLC-APCI-MS, an Agilent 1100 series LC/MSD SL, Alltech Prevail Cyano column, $150 \times 2.1 \mathrm{~mm} \times 3 \mu \mathrm{m}$ ) in a selected ion monitoring (SIM) mode according to Schouten et al. (2007). Quantification of the GDGTs was achieved by integrating the peak areas and using a $\mathrm{C}_{46}$ GDGT internal standard according to Huguet et al. (2006).

\subsection{Long-chain $\boldsymbol{n}$-alkanes carbon isotopes}

Two sediment samples collected in the LW season, one from Lake Janauaca and another from Lake Curuai, were used to compare the differences in the $\delta^{13} \mathrm{C}$ values of plantwax-derived long-chain $n$-alkanes in the upstream and in the downstream lakes. The extraction of $n$-alkanes was performed with an accelerated solvent extraction (ASE) method. The extracts were fractionated in apolar and polar fractions using an activated aluminum oxide $\left(\mathrm{Al}_{2} \mathrm{O}_{3}\right)$ column with hexane and $\mathrm{MeOH}: \mathrm{DCM}(1: 1, v: v)$, respectively, as the eluents. $n$-alkanes in the apolar fractions were identified by a Thermo Finnigan Trace DSQ gas chromatograph mass spectrometry (GC-MS) and quantified with an HP 6890 GC system. To quantify the concentration of the $n$-alkanes, an internal standard was added to the apolar extracts. To further clean up the apolar fraction, the extracts were passed over a silver nitrate $\left(\mathrm{AgNO}_{3}\right)$ column using hexane as the eluent. The $\delta^{13} \mathrm{C}$ values of higher $n$-alkanes were determined using an isotope-ratio-monitoring mass spectrometer (IRM-GC-MS) Thermo Delta V Advantage and the results were obtained using the software Isodat 3.0. Isotope values were measured against calibrated external reference gas and performance of the instrument was monitored by daily injects of a mixture of a $\mathrm{C}_{20}$ and a $\mathrm{C}_{24}$ perdeuterated $n$-alkane with known isotopic compositions. The $\delta^{13} \mathrm{C}$ values for the $n$-alkanes are reported in the standard delta notation against the Vienna Pee Dee Belemnite (VPDB) standard. All samples were run four 

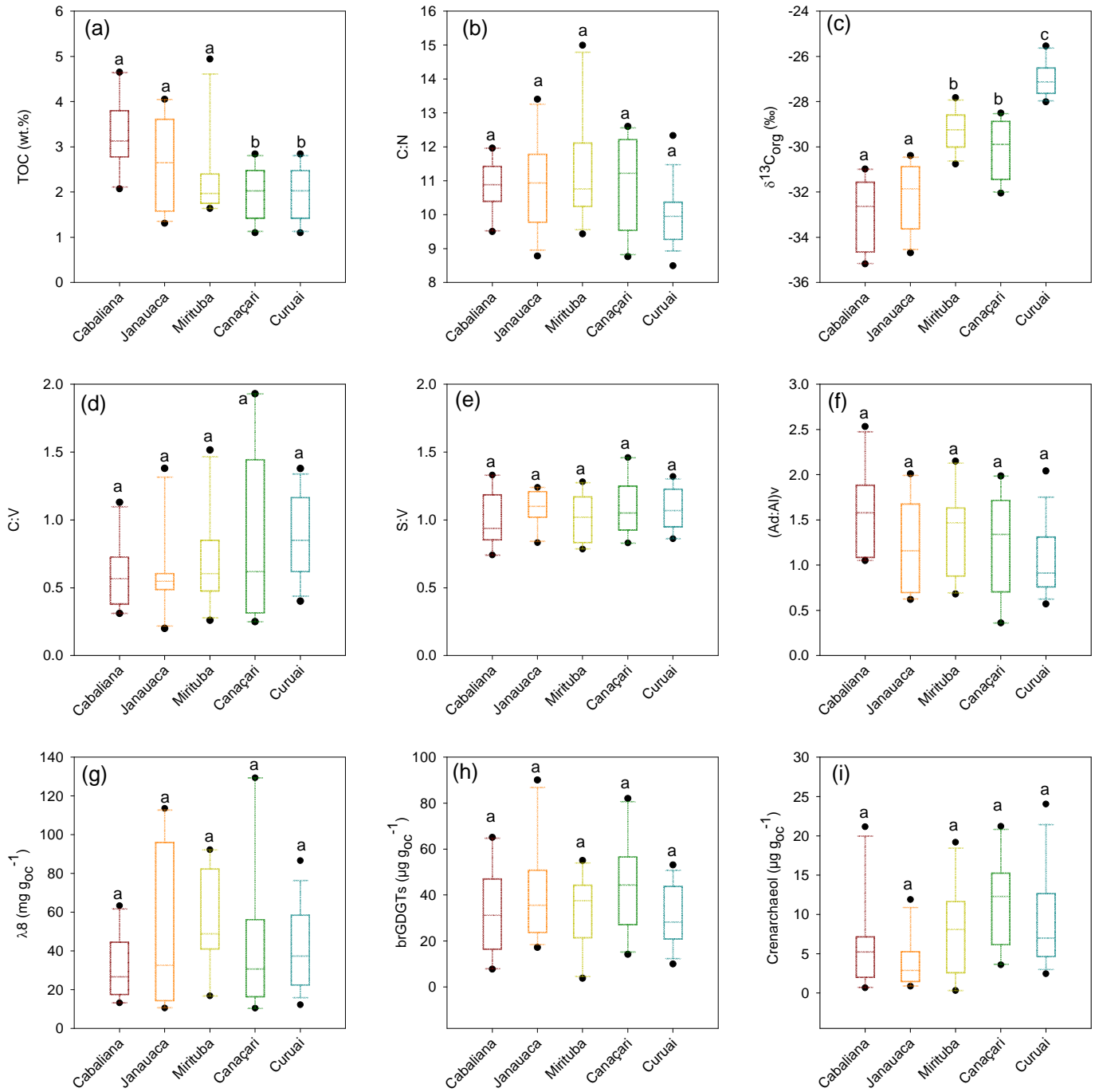

Figure 3. Box plots of bulk OC parameters, lignin phenols, and GDGTs along the upstream-downstream transect. The midpoint of a box plot is the mean. The 25 and $75 \%$ quartiles define the hinges (end of the boxes), and the difference between the hinges is the spread. Letters indicate statistically significant groups of data $(p<0.05)$.

times with an average standard deviation of $0.3 \%$ ofor the $\mathrm{C}_{25}$ $n$-alkane, $0.3 \%$ ofor the $\mathrm{C}_{29} n$-alkane and $0.2 \%$ or the $\mathrm{C}_{31}$ $n$-alkane (Sinninghe-Damsté et al., 2011).

\subsection{Statistical analysis}

To evaluate the differences in mean values between different groups, the non-parametric Mann-Whitney $U$ test was used, which does not meet the normality assumption of the oneway analysis variance (ANOVA). Groups that showed significant differences $(p<0.05)$ were assigned with different letters. The statistical test was performed with the software package SIGMAPLOT 13.0.

\section{Results}

\subsection{Bulk parameters}

The TOC content was the lowest in the downstream Lake Curuai $(2.0 \pm 0.6$ wt. \%) and the highest in Lake Cabaliana $(3.3 \pm 0.8$ wt. \%) (Fig. 3a, Table 3). No significant seasonal variation was observed ( $p=0.145)$ (Fig. $4 a)$. The $\mathrm{C}: \mathrm{N}$ ratio did not reveal significant spatial $(p=0.104)$ or seasonal $(p=0.418)$ variations (Figs. $3 \mathrm{~b}$ and $4 \mathrm{~b})$. The $\delta^{13} \mathrm{C}_{\mathrm{org}}$ values were significantly less negative in the downstream lakes $(p<0.001)$ (Fig. 3c). In Lake Curuai the mean value was $-27 \pm 1 \%$ and in Lake Cabaliana $-33 \pm 2 \%$. No significant $(p=0.968)$ seasonal variation was observed for the $\delta^{13} \mathrm{C}_{\text {org }}$ values (Fig. $4 \mathrm{c}$ ). 
Table 2. Values of bulk parameters and lignin phenols in wetlands, terrestrial ("terra firme") and aquatic sources of sedimentary OC.

\begin{tabular}{|c|c|c|c|c|c|c|c|}
\hline & $\begin{array}{r}\text { TOC } \\
\text { (wt. \%) }\end{array}$ & $\mathrm{C}: \mathrm{N}$ & $\begin{array}{r}\delta^{13} \mathrm{C}_{\mathrm{org}} \\
(\% \circ \mathrm{VPDB})\end{array}$ & $\begin{array}{r}\lambda 8 \\
\left(\mathrm{mg} \mathrm{g}_{\mathrm{OC}}^{-1}\right)\end{array}$ & $C: V$ & $S: V$ & $(\mathrm{Ad}: \mathrm{Al}) v$ \\
\hline \multicolumn{8}{|l|}{ Macrophytes } \\
\hline Eleocharis sp. (root) & 27.2 & 15 & -32.3 & 47.5 & 3.7 & 0.6 & 0.1 \\
\hline Eleocharis sp. & 42.3 & 24.1 & -30.5 & 56.6 & 3.1 & 0.6 & 0.8 \\
\hline Pistia stratiotes & 37.1 & 15 & -29.7 & 25.9 & 0.4 & 0.9 & 0.1 \\
\hline Paspalum repens & 41.6 & 14.9 & -12.6 & 47.9 & 1.7 & 0.4 & 0.1 \\
\hline Paspalum repens (root) & 38.5 & 27.1 & -13.6 & 93.9 & 4 & 0.7 & 0.2 \\
\hline \multicolumn{8}{|l|}{ Wetland soil } \\
\hline Janauaca & 0.6 & 6.1 & -27.3 & 25.5 & 0.2 & 0.6 & 1.2 \\
\hline Janauaca stream & 0.4 & 8.3 & -27.8 & 63.2 & 0.5 & 1.1 & 1 \\
\hline Amazon River & 0.4 & 9.8 & -28.4 & 9 & 0.5 & 1 & 1.3 \\
\hline Amazon River & 1 & 6.7 & -18.7 & 67.5 & 0.5 & 0.9 & 0.9 \\
\hline \multicolumn{8}{|l|}{ Soil (terra firme) } \\
\hline Canaçari & 2.1 & 16.3 & -27.4 & 36.6 & 0.3 & 0.8 & 0.6 \\
\hline Amazon River & 4.2 & 14 & -28.7 & 9.7 & 0.5 & 0.5 & 1.4 \\
\hline Amazon River & 2.3 & 11.1 & -29 & 88.3 & 0.4 & 0.5 & 1.5 \\
\hline
\end{tabular}

Table 3. Average values for the seasonality and spatiality of bulk parameters, lignin phenols and GDGTs in sediment samples from the floodplain lakes.

\begin{tabular}{|c|c|c|c|c|c|c|c|c|c|c|c|c|}
\hline & $n$ & $\begin{array}{c}\text { TOC } \\
\text { (wt. \%) }\end{array}$ & $C: N$ & $\begin{array}{l}\delta^{13} \mathrm{C}_{\mathrm{org}} \\
(\% \circ \mathrm{VPDB})\end{array}$ & $\begin{array}{c}\Lambda 8 \\
\left(\mathrm{mg} \mathrm{g}_{\mathrm{oc}}^{-1}\right)\end{array}$ & $C: V$ & $S: V$ & $(\mathrm{Ad}: \mathrm{Al}) v$ & $\begin{array}{c}\text { brGDGTs } \\
\left(\mu \mathrm{g} \mathrm{g}_{\mathrm{OC}}^{-1}\right)\end{array}$ & $\begin{array}{l}\text { Crenarchaeol } \\
\left(\mu g_{\mathrm{OC}}^{-1}\right)\end{array}$ & $\begin{array}{c}\text { IPL } \\
\text { brGDGTs }(\%)\end{array}$ & $\begin{array}{c}\text { IPL } \\
\text { crenarchaeol }(\%)\end{array}$ \\
\hline Cabaliana & 10 & $3.3 \pm 0.8$ & $10.9 \pm 0.8$ & $-33.0 \pm 1.6$ & $32 \pm 17$ & $0.6 \pm 0.3$ & $1.0 \pm 0.2$ & $1.6 \pm 0.5$ & $33 \pm 19$ & $6 \pm 6$ & $15 \pm 8$ & $9 \pm 8$ \\
\hline Janauaca & 11 & $2.7 \pm 1.0$ & $10.9 \pm 1.4$ & $-32.2 \pm 1.5$ & $50 \pm 41$ & $0.6 \pm 0.3$ & $1.1 \pm 0.1$ & $1.2 \pm 0.5$ & $41 \pm 23$ & $4 \pm 3$ & $14 \pm 9$ & $15 \pm 9$ \\
\hline Mirituba & 11 & $2.3 \pm 1.0$ & $11.3 \pm 1.7$ & $-29.3 \pm 0.9$ & $57 \pm 26$ & $0.7 \pm 0.4$ & $1.0 \pm 0.2$ & $1.4 \pm 0.5$ & $33 \pm 16$ & $8 \pm 6$ & $14 \pm 8$ & $18 \pm 10$ \\
\hline Canaçari & 10 & $2.0 \pm 0.6$ & $10.9 \pm 1.4$ & $-30.0 \pm 1.3$ & $42 \pm 38$ & $0.9 \pm 0.6$ & $1.1 \pm 0.2$ & $1.2 \pm 0.6$ & $44 \pm 21$ & $12 \pm 6$ & $9 \pm 8$ & $11 \pm 9$ \\
\hline Curuai & 15 & $2.1 \pm 0.4$ & $10.0 \pm 0.9$ & $-27.0 \pm 0.8$ & $41 \pm 21$ & $0.9 \pm 0.3$ & $1.1 \pm 0.2$ & $1.0 \pm 0.4$ & $31 \pm 14$ & $9 \pm 7$ & $9 \pm 7$ & $15 \pm 10$ \\
\hline LW & 12 & $2.3 \pm 0.2$ & $10.2 \pm 1.2$ & $-30.0 \pm 2.3$ & $29 \pm 12$ & $0.7 \pm 0.4$ & $0.9 \pm 0.1$ & $1.5 \pm 0.4$ & $38 \pm 16$ & $10 \pm 6$ & $19 \pm 7$ & $23 \pm 9$ \\
\hline RW & 15 & $2.7 \pm 0.8$ & $10.6 \pm 1.3$ & $-30.1 \pm 2.5$ & $56 \pm 30$ & $0.8 \pm 0.5$ & $1.1 \pm 0.2$ & $1.0 \pm 0.5$ & $35 \pm 12$ & $7 \pm 5$ & $8 \pm 6$ & $10 \pm 5$ \\
\hline HW & 12 & $2.6 \pm 1.1$ & $11.1 \pm 1.5$ & $-29.7 \pm 3.0$ & $23 \pm 9$ & $0.8 \pm 0.4$ & $1.0 \pm 0.2$ & $1.7 \pm 0.5$ & $24 \pm 16$ & $4 \pm 4$ & $10 \pm 9$ & $17 \pm 16$ \\
\hline FW & 18 & $2.2 \pm 0.9$ & $11.0 \pm 1.3$ & $-30.2 \pm 2.4$ & $62 \pm 33$ & $0.6 \pm 0.2$ & $1.1 \pm 0.2$ & $1.1 \pm 0.4$ & $45 \pm 23$ & $9 \pm 7$ & $9 \pm 9$ & $8 \pm 7$ \\
\hline
\end{tabular}

The $\delta^{13} \mathrm{C}_{\text {org }}$ values in "terra firme" soils and wetland soils varied between -29 and $-19 \%$ o $(n=7)$. These samples were collected in the Amazon River margin between Canaçari and Curuai. The $\mathrm{C}: \mathrm{N}$ ratio values varied between 6 and $16(n=7)$ (Table 3$)$. The $\mathrm{C}_{4}$ macrophytes samples (Paspalum repens) showed values of $\delta^{13} \mathrm{C}_{\text {org }}$ between -14 and $-13 \%$ and values of the $\mathrm{C}: \mathrm{N}$ ratio between 15 and 27 . The $\mathrm{C}_{3}$ macrophytes (Eleocharis sp. and Pistia stratiotes) had $\delta^{13} \mathrm{C}_{\text {org }}$ values between -30 and $-33 \%$ and $\mathrm{C}: \mathrm{N}$ ratios between 15 and 24 (Table 2).

\subsection{Lignin phenols}

No significant changes $(p=0.392)$ were observed along the upstream-downstream transect for the mean values of $\lambda 8$ (i.e., a proxy for the amount of lignin normalized to OC); The mean value of $\lambda 8$, a proxy for the amount of lignin normalized to OC, for the soil OC was $44 \pm 29 \mathrm{mg} \mathrm{g}_{\mathrm{oc}}^{-1}$. No significant changes $(p=0.392)$ were observed along the upstream-downstream transect for the mean values of $\lambda 8)$. However, $\lambda 8$ values revealed significant seasonal changes $(p=0.001)$. The higher values were observed in the RW $\left(56 \pm 30 \mathrm{mg} \mathrm{g}_{\mathrm{oc}}^{-1}\right)$ and in the FW seasons $\left(62 \pm 34 \mathrm{mg} \mathrm{g}_{\mathrm{oc}}^{-1}\right)$ compared to the HW $\left(23 \pm 9 \mathrm{mg} \mathrm{g}_{\mathrm{oc}}^{-1}\right)$ and LW (29 $\left.\pm 12 \mathrm{mg} \mathrm{g}_{\mathrm{oc}}^{-1}\right)$ seasons (Fig. 4g). The $C: V$ ratio showed no significant seasonal $(p=0.609)$ and spatial variation $(p=0.214)$, and the mean value for all sediments was $0.7 \pm 0.4$ (Figs. $3 \mathrm{~d}$ and $4 \mathrm{~d}$ ). The values of the $S: V$ ratio also do not show significant spatial $(p=0.568)$ or seasonal ( $p=0.08)$ differences. The mean values for the lakes were approximately $1.1 \pm 0.1$ and the mean seasonal values varied between $0.9 \pm 0.1$ and $1.1 \pm 0.2$ (Fig. $4 \mathrm{e}$ and Table 3). The mean value of $(\mathrm{Ad}: \mathrm{Al}) v$ ratio for the different lakes does not show spatial variation ( $p=0.137$ ) (Fig. 3f) - however, it was higher in the LW $(1.5 \pm 0.4)$ and $\mathrm{HW}(1.7 \pm 0.5)$ seasons $(p<0.001)$ (Fig. 4f).

For the $\mathrm{C}_{3}$ macrophytes, $\lambda 8$ values varied between 26 and $67 \mathrm{mg} \mathrm{g}_{O C-}^{1}$ and between 48 and $94 \mathrm{mg} \mathrm{g}_{O C}^{-1}$ for the $\mathrm{C}_{4}$ 

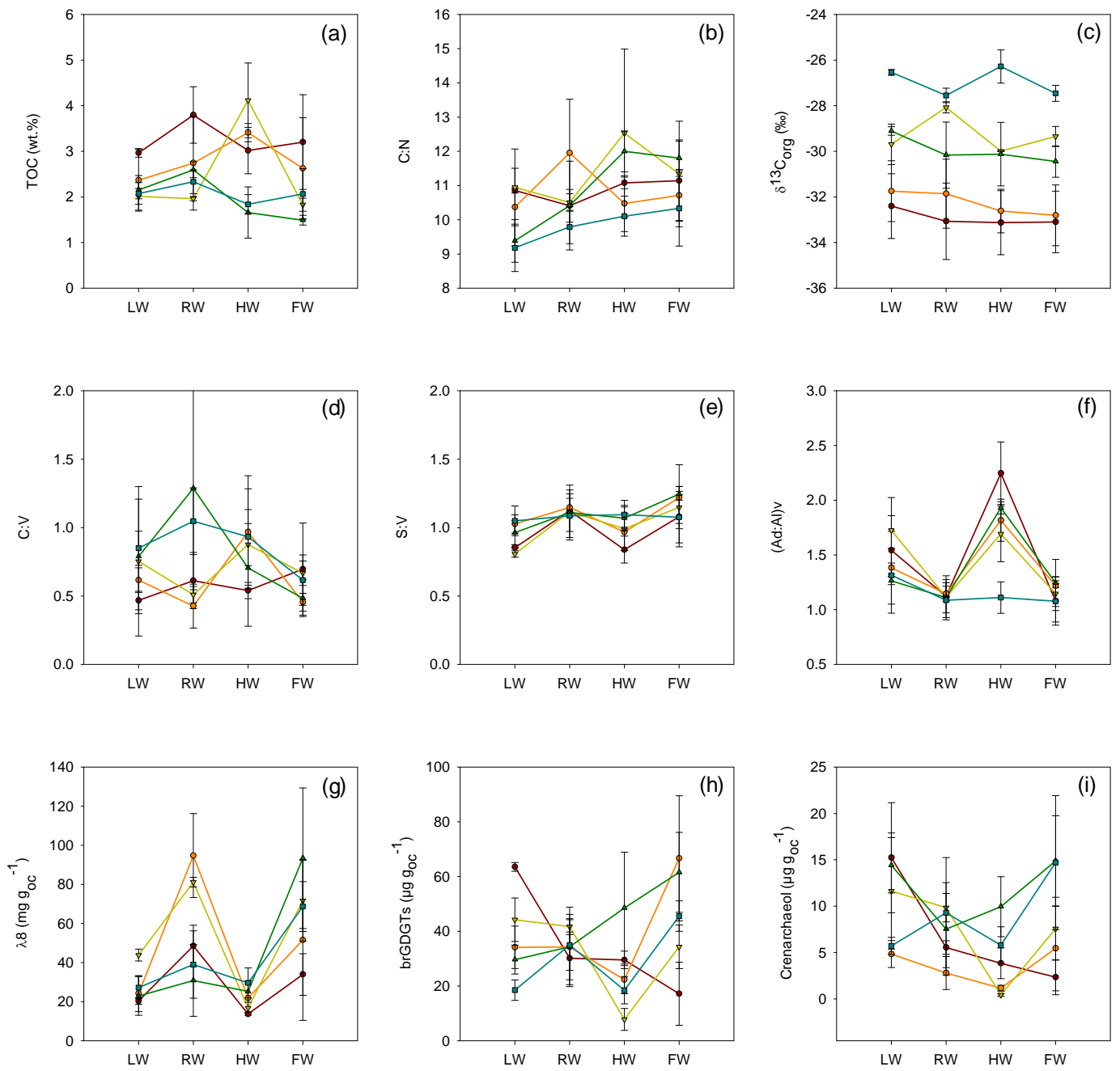

$\multimap$ Cabaliana $\multimap$ Janauaca $\multimap$ Mirituba $\rightarrow$ Canaçari $\multimap$ Curuai

Figure 4. Box plots of total lignin phenols ( $\lambda 8$ ), and GDGTs for four hydrological seasons. The midpoint of a box plot is the mean. The 25 and $75 \%$ quartiles define the hinges (end of the boxes), and the difference between the hinges is the spread. Letters indicate statistically significant groups of data $(p<0.05)$.

macrophytes. The $S: V$ ratio varied between 0.6 and 0.9 for $\mathrm{C}_{3}$ macrophytes and between 0.4 and 0.7 for the $\mathrm{C}_{4}$ macrophytes. The range of $C: V$ ratio was $0.4-3.7$ for the $\mathrm{C}_{3}$ macrophytes and 1.7-4.0 for the $\mathrm{C}_{4}$ macrophytes. The $(\mathrm{Ad}: \mathrm{Al}) v$ ratio varied between 0.2 and 0.8 for all macrophyte samples (Table 3). For the "terra firme" soil and wetland soil samples, the $\lambda 8$ values varied between 9 and $88 \mathrm{mgg}^{-1}$. The $S: V$ ratio varied between 0.5 and 1.1 , the $C: V$ ratio varied between 0.2 and 0.5 , and the $(\mathrm{Ad}: \mathrm{Al}) v$ ratio varied between 0.6 and 1.5 .

\subsection{BrGDGTs and crenarchaeol}

Along the upstream-downstream transect, no significant changes $(p=0.371)$ were observed for the mean values of brGDGTs concentrations (Fig. 3h). The lowest value was found in Curuai $\left(31 \pm 14 \mu \mathrm{g} \mathrm{g}_{\mathrm{oc}}^{-1}\right)$ and the highest one in Canaçari $\left(44 \pm 22 \mu \mathrm{g} \mathrm{goc}_{\mathrm{oc}}^{-1}\right)$. The average concentration of crenarchaeol was higher in Canaçari $\left(12 \pm 6 \mu \mathrm{g} \mathrm{goc}^{-1}\right)$ when compared to Janauaca $\left(4 \pm 3 \mu \mathrm{g} \mathrm{goc}_{\text {oc }}^{-1}\right)$. However, no significant difference ( $p=0.127$ ) was observed between the upstream $(\mathrm{Ca}-$ baliana and Janauaca) lakes and the downstream lake $(\mathrm{Cu}-$ ruai) (Fig. 3h and i). On the other hand, brGDGTs concentrations showed significant seasonal changes $(p=0.025)$. The 
Table 4. Values of long-chain $n$-alkanes $\delta^{13} \mathrm{C}$ in surface sediment samples from the upstream Lake Janauaca and the downstream Lake Curuai. The samples were collected in the LW season.

\begin{tabular}{lccc}
\hline & $\mathrm{C}_{27}$ & $\mathrm{C}_{29}$ & $\mathrm{C}_{31}$ \\
\hline Janauaca & $-33.7 \pm 0.2$ & $-33.8 \pm 0.2$ & $-34.8 \pm 0.2$ \\
Curuai & $-31.2 \pm 0.3$ & $-31.5 \pm 0.3$ & $-32.2 \pm 0.3$ \\
\hline
\end{tabular}

highest mean value for brGDGTs concentrations was found in the FW season $\left(45 \pm 23 \mu \mathrm{g} \mathrm{g}_{\mathrm{oc}}^{-1}\right)$, and the lowest mean concentration was found in the HW season $\left(24 \pm 16 \mu \mathrm{g} \mathrm{g} \mathrm{g}_{\text {oc }}^{-1}\right)$. The RW and LW seasons showed intermediate mean concentrations ( $35 \pm 12 \mu \mathrm{g} \mathrm{goc}_{\mathrm{oc}}^{-1}$ and $38 \pm 16 \mu \mathrm{g} \mathrm{g}_{\mathrm{oc}}^{-1}$, respectively) and no significant difference ( $p=0.335)$ was observed if compared to the FW and HW seasons (Fig. 4h).

The concentrations of crenarchaeol did not reveal significant changes $(p=0.096)$ over the hydrological seasons (Fig. 4i). The mean values varied between $4 \pm 4 \mu \mathrm{g} \mathrm{goc}_{\text {oc }}^{-1}$ and $10 \pm 6 \mu \mathrm{g} \mathrm{g}_{\mathrm{oc}}^{-1}$ in the HW and LW seasons, respectively. The percentage of IPL brGDGTs and IPL crenarchaeol was significantly higher ( $p=0.002$ and $p<0.001$, respectively) in the LW season (19 \pm 7 and $23 \pm 9 \%$, respectively). In the other three seasons, it showed values around $10 \pm 2 \%$ of IPL brGDGTs and IPL crenarchaeol with no significant variability (Table 3 ).

\subsection{Long-chain $n$-alkanes}

The results of $n$-alkane analyses are summarized in Table 4 . The carbon preference indices (CPI), calculated according to Bray and Evans (1961), were high, confirming a plant wax origin of the higher $n$-alkanes. A somewhat lower CPI (3.5) was found in the downstream lake compared to those in the upstream lake (5.5). A significant increase in the $\delta^{13} \mathrm{C}$ values of the long-chain $n$-alkanes $\left(\mathrm{C}_{27}, \mathrm{C}_{29}, \mathrm{C}_{31}\right)$ was observed downstream. In the upstream lake, the mean $\delta^{13} \mathrm{C}$ for the long-chain $n$-alkanes was $-34.1 \pm 0.5 \%$ and in the downstream lake the mean value was $-31.6 \pm 0.6 \%$ (Table 4 ). This represents a difference of $2.5 \%$ from upstream to downstream.

\section{Discussion}

\subsection{Sources of sedimentary organic matter in the floodplain lakes}

To determine the origin of the SOM in the floodplain lakes, we considered five potentially significant sources in the central Amazon basin (Hedges et al., 1986; Moreira-Turcq et al. 2013; Mortillaro et al., 2011): (1) the terrestrial Andean claybounded and refractory SPOM, which may be transferred to the floodplain lakes via the Solimões-Amazon and Madeira rivers (Hess et al., 2003), (2) "terra firme" soils and litters of the Amazonian lowland forests (non-floodable forests), which will be transferred to the floodplain lakes via local streams, (3) the wetland soils (flooded forests) and litters (leaves, grasses, woods, etc.), transferred to the floodplain lakes during the receding waters (FW season) or in the rainy season (RW season) (Schöngart et al., 2010), (4) the wetland aquatic and semi-aquatic macrophyte vegetation of the floodplain lakes (Junk, 1997; Moreira-Turcq et al., 2004; Mortillaro et al., 2011), and (5) phytoplankton from the river or produced in the lake itself (Moreira-Turcq et al., 2004; Mortillaro et al., 2011). The biomarkers analyzed, lignin phenols and GDGTs, enabled us to identify most of these sources of OM, except for planktonic sources. However, in this case, some information can be obtained using bulk parameters i.e., the $\delta^{13} \mathrm{C}_{\text {org }}$ and $\mathrm{C}: \mathrm{N}$ ratio. Our results were compared with data reported previously (Hedges et al., 1986; Martinelli et al., 1994, 2003; Meyers], 1994; Aufdenkampe et al., 2007; Zell et al., 2013b) and with specific OM sources sampled and analyzed in this work, such as macrophytes, wetland soil and "terra firme" soil (Table 3), in order to identify the main sources of SOM in the floodplain lakes.

The average values of the various parameters of the river SPOM (Ertel et al., 1986; Hedges et al., 1986), wetland soils, "terra firme" soils and the potential biological OM sources (phytoplankton, macrophytes, grass, leaves and wood) are compared with those of the SOM of the floodplain lakes in Fig. 5 and Table 5. Data for the riverine SPOM are subdivided into fine particulate organic matter (FPOM) and coarse particulate organic matter (CPOM). For the interpretation of these data, it is important to note that the amount of CPOM in the Amazon River has been reported to be approximately eight times lower than that of the FPOM (Richey et al., 1990). The averages of important lignin parameters ( $\lambda 8, S: V$ ratio) but also the $\mathrm{C}: \mathrm{N}$ ratio of the wood samples are significantly different $(p<0.001)$ from those for the sediments, which clearly indicates only a minor contribution of woody material to the SOM. Furthermore, the $\lambda 8$ of riverine FPOM is substantially lower than that of the SOM of the floodplain lakes, indicating that riverine SPOM is not an important source of lignin for the SOM of the floodplain lakes either. In terms of lignin parameters, the SOM is distinguished by two clear characteristics. Firstly, the (Ad : $\mathrm{Al}) v$ ratio is high with an average value of 1.25 (Fig. 5). Such a high value is only noted in the wetland and "terra firme" soils. However, this ratio is affected by the oxidation state of the lignin, and thus cannot be used as a source characteristic of the lignin. Secondly, the SOM is characterized by a substantially elevated $C: V$ ratio (Fig. 6; see Hedges et al., 1982). Since all of the potential lignin sources, except macrophytes, have a much lower value, this indicates that macrophyte lignin and, thus accordingly, macrophyte OM (since average $\lambda 8$ values of macrophyte OM and the SOM do not substantially differ) largely contribute to the SOM. Since the $S: V$ ratio of macrophyte $\mathrm{OM}$ is relatively lower than that of the lignin component of the SOM (Fig. 5), some contributions of lignin derived from other fresh plant OM (i.e., 

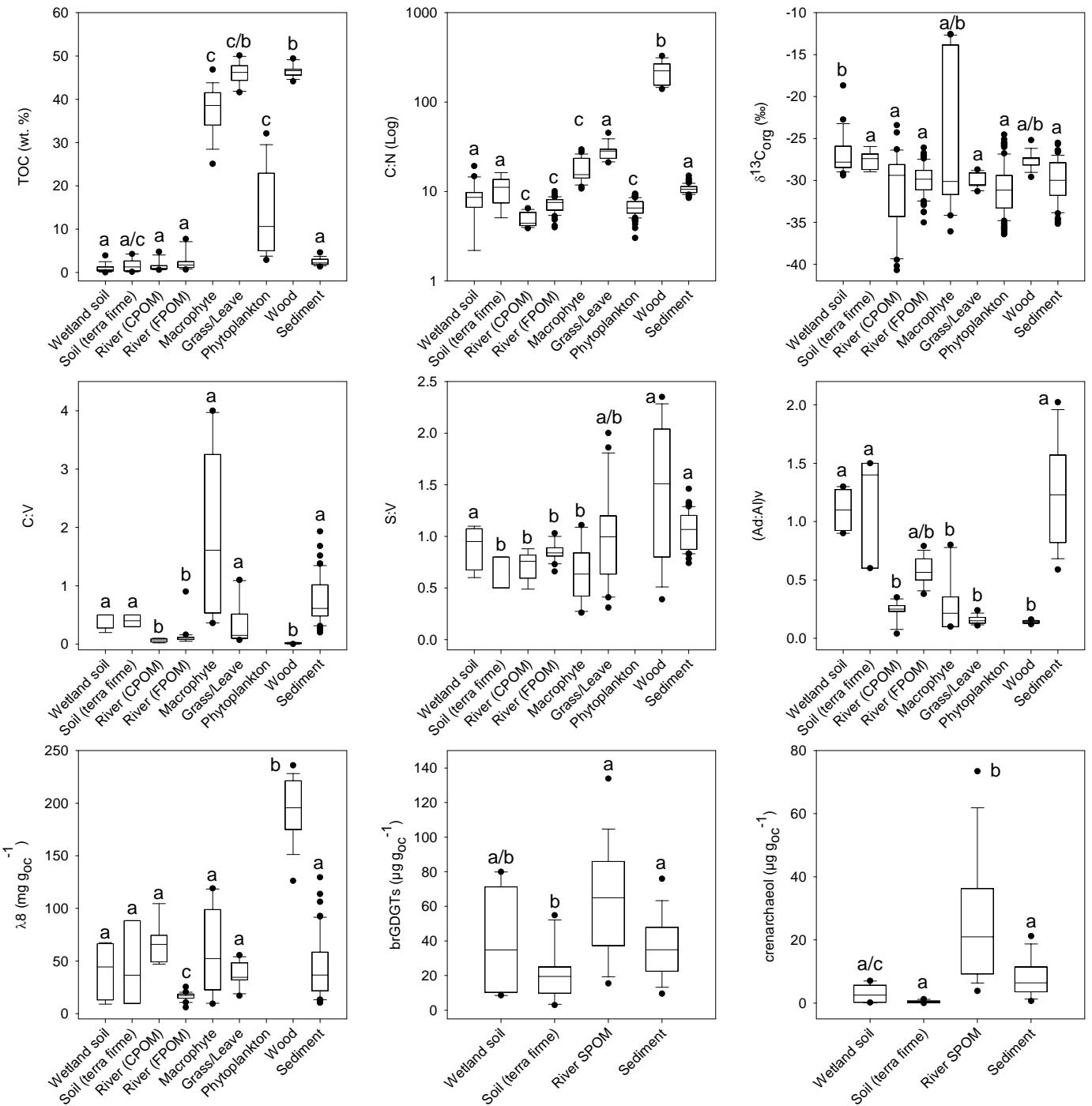

Figure 5. Box plots of average values of multiple biomarkers and bulk parameters in sediment samples and in potential sources on SOM. Data is based on previous studies (Hedges et al., 1986; Aufdenkampe et al., 2007; Zell et al., 2013b) and the present work (Table 3). Letters over the boxes indicate significant differences $(p<0.05)$ between the means.

Table 5. Average values of biomarkers and bulk parameters in the possible sources of SOM and in sediment samples. The data were obtained in the present work and from the literature (Hedges et al., 1986; Hedges and Mann, 1979; Aufdenkampe et al., 2007).

\begin{tabular}{lrrrrrrrrr}
\hline & $\begin{array}{r}\text { TOC } \\
(\mathrm{wt} . \%)\end{array}$ & $\mathrm{C}: \mathrm{N}$ & $\begin{array}{r}\delta^{13} \mathrm{C}_{\text {org }} \\
(\% \circ \mathrm{VPDB})\end{array}$ & $C: V$ & $S: V$ & $(\mathrm{Ad}: \mathrm{Al}) v$ & $\begin{array}{r}\lambda 8 \\
\left(\mathrm{mg} \mathrm{g}_{\mathrm{OC}}^{-1}\right)\end{array}$ & $\begin{array}{r}\text { brGDGTs } \\
\left(\mu \mathrm{g} \mathrm{g}_{\mathrm{OC}}^{-1}\right)\end{array}$ & $\begin{array}{r}\text { crenarchaeol } \\
\left(\mu \mathrm{g} \mathrm{g}_{\mathrm{OC}}^{-1}\right.\end{array}$ \\
\hline Wetland soil & 0.9 & 8.3 & -27.0 & 0.4 & 0.9 & 1.1 & 41.3 & 39.6 & 2.9 \\
Soil (terra firme) & 1.6 & 10.5 & -27.6 & 0.4 & 0.6 & 1.2 & 44.9 & 21.1 & 0.5 \\
River (CPOM) & 1.4 & 4.8 & -31.4 & 0.1 & 0.7 & 0.2 & 40.0 & & \\
River (FPOM) & 2.2 & 7.2 & -29.9 & 0.1 & 0.9 & 0.6 & 16.1 & 77.4 & 25.9 \\
Macrophyte & 36.6 & 28.7 & -24.7 & 1.9 & 0.6 & 0.3 & 59.0 & & \\
Grass/Leave & 46.7 & 28.1 & -30.1 & 0.4 & 1.1 & 0.2 & 37.2 & & \\
Phytoplankton & 13.9 & 6.7 & -31.1 & & & & & & \\
Wood & 46.5 & 217.7 & -27.6 & 0.0 & 1.5 & 0.1 & 193.3 & & \\
Sediment & 2.4 & 10.7 & -30.0 & 0.7 & 1.1 & 1.3 & 43.6 & 36.1 & \\
\hline
\end{tabular}


Table 6. Data used in Eqs. (1) and (2) to estimate the fraction of OM derived from macrophytes and aquatic OM to the SOM.

\begin{tabular}{lcccc|c}
\hline Parameter & SOM & Macrophytes & Rive SPOM & Other OM sources & $\begin{array}{c}\text { Estimated } \\
\text { fraction }(\%)\end{array}$ \\
\hline$C: V$ & $0.7 \pm 0.4$ & 1.9 & & 0.2 & 29 \\
crenarchaeol $\left(\mu \mathrm{gg}_{\mathrm{OC}}^{-1}\right)$ & $7.8 \pm 6.0$ & & 26.0 & 1.2 & 27 \\
\hline
\end{tabular}

grasses/leaves) or wetland soils might explain the elevated $S: V$ ratio of the SOM.

Further information with respect to sources of SOM can be obtained from the GDGT concentrations. The concentrations of both brGDGTs and crenarchaeol are higher in the riverine SPOM than in the SOM, pointing to a contribution of riverine SPOM to the SOM, in contrast to what was shown by the lignin phenols. However, the concentrations of brGDGTs in the wetland soils and river SPOM are statistically indistinguishable and, thus, it is not possible to use the brGDGTs as a specific OM source indicator. This is in line with the idea that brGDGTs can be produced in soils (e.g., Weijers et al., 2006), rivers (e.g., Zell et al., 2013a; De Jonge et al., 2015) and lake waters (e.g., Tierney et al., 2010; Buckles et al., 2014). On the other hand, riverine SPOM is the most likely $\mathrm{OM}$ source for the substantially increased concentration of crenarchaeol in the SOM of the floodplain lakes if compared to other sources (Fig. 5). Crenarchaeol is indeed produced in the Amazon River by nitrifying archaea that consume ammonium produced from degrading OM (Zell et al., 2013b). However, it is known that crenarchaeol is also produced in lakes (Blaga et al., 2011; Tierney and Russell, 2009), indicating that it may also be produced in the floodplain lakes. Crenarchaeol is, therefore, considered as an indicator of aquatic $\mathrm{OM}$ in this system. The enhanced concentrations of crenarchaeol in SOM thus indicate an increased contribution from riverine and/or lacustrine SPOM.

In terms of bulk parameters, the $\mathrm{C}: \mathrm{N}$ ratio in the $\mathrm{SOM}$ shows intermediate values between the riverine SPOM and the various OM sources but with no distinct average values between them. Moreover, the average values of $\delta^{13} \mathrm{C}_{\text {org }}$ are statistically equal for sediments and most sources of OM (except for the wetland soils), and the TOC do not show any significant difference between the soils samples ( $p=1.241)$, riverine SPOM ( $p=1.044)$ and lake sediments. Thus, it is not possible to discriminate any specific source of SOM based on the average values of the bulk parameters.

We have argued that the $C: V$ ratio and the crenarchaeol concentration are the only two parameters that clearly point out one specific source of SOM (i.e., macrophytes and aquatic OM from rivers or floodplain lakes, respectively). Consequently, these parameters can be applied to a two endmember model to estimate the fractions of each of these two sources in the SOM. According to this approach (Martinelli et al., 2003), the average $C: V$ values of macrophytes and the average values of other OM sources (wetland and non- flooded soils and SPOM) can be used to estimate the contribution of macrophyte OM to the SOM (Eq. 1). Similarly, the concentration of crenarchaeol in the riverine SPOM and its concentration in soil samples can be used to estimate the contribution of aquatic OM to the SOM (Eq. 2):

$$
\begin{aligned}
& F_{\text {macrophytes }}=\frac{C: V_{\mathrm{SOM}}-C: V_{(\mathrm{SPOM}+\text { forest })}}{C: V_{\text {macrophyte }}-C: V_{(\mathrm{SPOM}+\text { forest })}} \times 100 \\
& F_{\text {SPOM }}=\frac{\text { Cren }_{\text {SOM }}-\text { Cren }_{\text {(forest }+ \text { macrophyte })}}{\text { Cren }_{\text {SPOM }}-\text { Cren }_{(\text {forest }+ \text { macrophyte })}} \times 100 \\
& F_{\text {macrophyte }}+F_{\mathrm{SPOM}}+F_{\text {forest }}=\operatorname{SOM}(100 \%) .
\end{aligned}
$$

In Eqs. (1) and (2), the $F_{\text {macrophytes }}$ and $F_{\text {SPOM }}$ represent the estimated fractional abundance of macrophytes and aquatic OM in SOM, respectively. $C: V_{\text {SOM }}$ and Cren SOM $_{\text {are }}$ the average values of each parameter found in the sediment samples, $C: V_{\text {macrophytes }}$ and Crenspom are the values of the predominant source of the respective parameter and $C$ : $V_{\text {(SPOM }+ \text { forest) }}$ and $\mathrm{Cren}_{\text {(forest }+ \text { macrophyte) }}$ are the values of the other possible OM sources (Table 6). As discussed above, the high values of $(\mathrm{Ad}: \mathrm{Al}) v$ indicate that lignin components of the SOM is partially degraded, which may affect the values of the $C: V$ ratio. There are also numerous complications with the application of crenarchaeol as an indicator of aquatic matter in this ecosystem. Therefore, the presented mixing model should be considered as estimations. The results of Eqs. (1-3) indicate that $25-35 \%$ of the SOM is derived from macrophytes and $20-30 \%$ from aquatic $\mathrm{OM}$ sources (riverine and lacustrine SPOM) . Consequently, the remaining $35-55 \%$ of the SOM might be derived from the wetlands and non-flooded forests (Eq. 3). The periodic floods link the floodplain lakes and the wetland vegetation and soil. Thus, the seasonal and spatial contrasts in the SOM should be investigated in order to better understand the connectivity between these compartments.

\subsection{Spatial differences in the composition of sedimentary organic matter}

Along the longitudinal transect, from upstream to downstream, most bulk geochemical parameters (i.e., TOC content and $\delta^{13} \mathrm{C}_{\text {org }}$ ) show significant differences between the upstream and downstream lakes (Fig. 3a, c), while most of the 
measured biomarker parameters $(\lambda 8, S: V,(\mathrm{Ad}: \mathrm{Al}) v$ and brGDGTs) do not show such a pattern (Fig. $4 \mathrm{e}-\mathrm{h}$ ). On the other hand, the biomarker parameters show, in some cases, a clear seasonal contrast, which is not observed for the bulk parameters. Consequently, the bulk parameters apparently mix and homogenize the long timescale (year), while the biomarkers are more sensible to changes in short timescale (months) at the sediment surface. This observation is in agreement with previous studies about earlier diagenesis of organic molecules (Harvey, 2006). It is important to note that the results must be interpreted taking into consideration the high sedimentation rates in the floodplain lakes, typically $1-$ $2 \mathrm{~cm} \mathrm{yr}^{-1}$ (Moreira-Turcq et al., 2004), and the fact that resuspension is induced by storms during the LW and RW seasons or by currents during the receding waters (FW). These events may have a substantial effect on the material comprising the first $2 \mathrm{~cm}$ of sediments of floodplain lakes, which are mixed with newly arrived SOM from the water column, and are re-oxygenated favoring the degradation.

The percentage of TOC in the sediment samples shows a decrease from 3.3 (wt. \%) upstream (Cabaliana) to 2.1 (wt. \%) downstream (Curuai) (Fig. 3a). Furthermore, over the transect of lakes the average $\delta^{13} \mathrm{C}_{\text {org }}$ values increase by ca. $5 \%$ (Fig. 3c). However, the average $\mathrm{C}: \mathrm{N}$ ratio does not show any significant changes over the transect (Fig. 3b). These results are in good agreement with previous studies in the central Amazon basin (Victoria et al., 1992; Martinelli et al., 2003). The increasing trend in $\delta^{13} \mathrm{C}_{\text {org }}$ from upstream to downstream lakes may be caused by an increased contribution of $\mathrm{C}_{4}$ macrophytes to the SOM, whose abundance increases in open water lakes and floodplains. Alternatively, since the $\delta^{13} \mathrm{C}_{\text {org }}$ values in the downstream lakes come closer to the $\delta^{13} \mathrm{C}_{\text {org }}$ of the Solimões-Amazon SPOM $(\sim-23$ to $-30 \%)$, an increased input of riverine organic matter may also explain this. To disentangle whether this trend in the $\delta^{13} \mathrm{C}_{\text {org }}$ values is caused by an increased contribution of $\mathrm{C}_{4}$ plants or of riverine SPOM, the isotopic composition $\left(\delta^{13} \mathrm{C}\right)$ of long-chain $n$-alkanes, markers for higher plants, in sediments from the upstream Lake Janauaca and the downstream Lake Curuai, both collected during the LW season, was measured. The results (Table 4) show that the long-chain $n$-alkanes $\delta^{13} \mathrm{C}$ signature are more like those of $\mathrm{C}_{3}$ higher plants (Castañeda et al., 2009) for both lakes although for the Curuai the values are slightly less negative. If one considers the values of $\delta^{13} \mathrm{C}$ in the $n$-alkane $\mathrm{C}_{29}$ in the leaf waxes of $\mathrm{C}_{3}$ and $\mathrm{C}_{4}$ plants, one can calculate the contribution of $\mathrm{C}_{4}$ plants sedimentary $n$-alkanes according to the following equation:

$\mathrm{C}_{4}$ plants $(\%)=\frac{\left.\delta^{13} \mathrm{C}_{\text {org }} C_{29}\left(\mathrm{C}_{3} \text { plants }\right)-\delta^{13} \mathrm{C}_{\text {org }} \mathrm{C}_{29} \text { (sediment }\right)}{\delta^{13} \mathrm{C}_{\text {org }} \mathrm{C}_{29}\left(\mathrm{C}_{3} \text { plants }\right)-\delta^{13} \mathrm{C}_{\text {org }} \mathrm{C}_{29}\left(\mathrm{C}_{4} \text { plants }\right)} \times 100$,

where the end member value for $\delta^{13} \mathrm{C}_{\text {org }} \mathrm{C}_{29}\left(\mathrm{C}_{3}\right.$ plants) is $-34.7 \%$ and for $\delta^{13} \mathrm{C}_{\text {org }} \mathrm{C}_{29}$ ( $\mathrm{C}_{4}$ plants) is $-21.7 \%$ (Castañeda et al., 2009). The measured values for $\delta^{13} \mathrm{C}_{\text {org }}$ of the $\mathrm{C}_{29} n$-alkane in the sediments of Janauaca and Curuai are
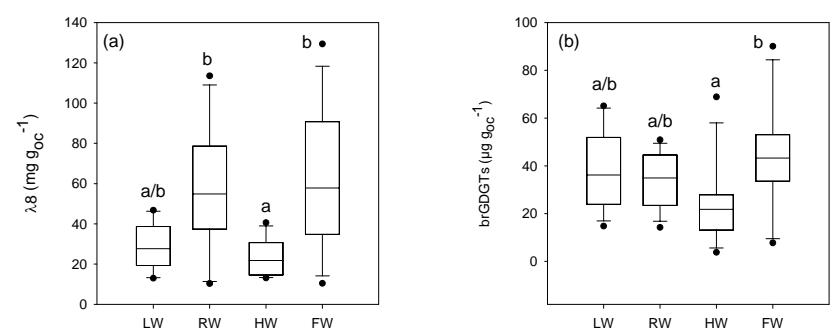

Figure 6. Box plots of seasonal average values of total lignin phenol and brGDGTs. Letters indicate statistically significant groups of data $(p<0.05)$.

listed in Table 4. Accordingly, the fraction of $\mathrm{C}_{4}$ plants in the SOM in the upstream lake is only $3 \%$, but for the downstream lake $22 \%$. The difference in $\delta^{13} \mathrm{C}_{\text {org }}$ for $\mathrm{C}_{4}$ and $\mathrm{C}_{3}$ higher plants is ca. $20 \%$. A switch from almost $100 \% \mathrm{C}_{3}$ macrophytes to a $78 \%$ contribution would result in a change in the isotopic composition of the macrophyte "pool" of the SOM of $4-4.5 \%$. Since this pool is estimated to represent $20-30 \%$ of the SOM, this cannot fully explain the observed $5 \%$ o shift (Fig. 3c). However, it should be considered that this increasing contribution of $\mathrm{C}_{4}$ higher plants in the downstream lake may not solely be the consequence of the change in the composition of the contributing aquatic macrophytes, but that also changes in the floodplain soil, mainly covered by shrubs and grass vegetation, may contribute to the observed shift in $\delta^{13} \mathrm{C}_{\text {org }}$ of SOM.

\subsection{Seasonal changes in the composition of sedimentary organic matter}

The two centimeters of surface sediment we have characterized in this study potentially integrate more than 1 year of sedimentation in such floodplain environment (MoreiraTurcq et al., 2004). However, because of the occurrence of pulsated inputs as well as resuspension, mixing and degradation processes in these superficial sediments (Moreira-Turcq et al., 2013), changes in the composition of superficial sediment apparently occurred at the seasonal scale (Fig. 4 and Table 3 ). Indeed, the $\lambda 8$ values showed significantly higher values in the RW and FW seasons than in the LW and HW seasons in all lakes (Figs. 4e-g, and 6a). The mean concentrations of brGDGTs also showed higher values in the FW season than in the HW season (Figs. $4 \mathrm{~h}$ and 6b). The cooccurrence of these two types of molecules indicates that litter, traced by lignin phenols, and superficial soils, traced by brGDGTs, are preferentially deposited in the floodplain lakes during rising and receding waters. In addition, the seasonal mean values of $(\mathrm{Ad}: \mathrm{Al}) v$ showed remarkably lower values in the RW and FW seasons (Fig. 4f), an inverse pattern if compared to the $\lambda 8$ and brGDGTs. This suggests that less degraded lignin phenols were present in the surface sediments in the RW and FW seasons. Thus, in this case, the increase in the concentrations of the organic compounds was 
not a consequence of the resuspension of the sediments, but due to a sudden arrival of fresher OM. In the HW and LW seasons, more degraded lignin phenols (i.e., higher values of $\mathrm{Ad}: \mathrm{Al} v$ ) were present in the sediments concomitant with lower amounts of $\lambda 8$. A possible process which is responsible for the $\lambda 8$ and brGDGTs transfer to the lakes' sediments is the connection of the Amazon River main stem with the local catchment areas such as wetlands and non-flooded forests during the RW and FW seasons. The lignin concentration could also increase as a consequence of the macrophyte communities while the brGDGTs could increase due to the in situ production in the floodplain lakes. However, the concentrations of crenarchaeol and IPL brGDGTs as well as $C: V$ ratio do not reveal significant seasonal changes (Table 3 and Fig. 4). Based on these observations, we interpret that these changes in the lignin phenols in the RW and FW seasons and the brGDGTs in the FW season were not derived from the lake in situ production but from soil and leaf runoffs.

Previous studies postulated that Andean and lowland soils are mainly transferred to the lakes via the Amazon River main stem, in particular during the RW and HW seasons and that they would be the main source of SOM in the floodplain lakes (e.g., Victoria et al., 1992; Moreira-Turcq et al., 2004; Mortillaro et al., 2011). However, according to our results, the lignin phenols increased their concentration in the RW and the FW seasons. The hydrodynamics of floodplain lakes and their connections to the local drainage flooded forests and the main stem (Bourgoin et al., 2007; Bonnet et al., 2008), and the analysis of biomarkers applied in this study, suggest that in the RW and FW seasons, these organic molecules are mainly derived from the drainage of local wetlands and lowland "terra firme" soils. This is more evident for the upstream lakes surrounded by larger flooded forests than for the downstream lakes surrounded mainly by grass vegetation and shrubs. Even if in Lake Curuai, phytoplankton primary production and the riverine SPOM are potentially important sources of SOM (Moreira-Turcq et al., 2004; Zocatelli et al., 2013), this material is not predominant in the sediments, compared to the material coming from the interface between the lake and the wetland, which is determinant for the sedimentation of the organic compounds.

\section{Conclusion}

Our results suggest that the vegetation coverage of the wetlands (flooded forests) and "terra firme" (non-floodable forests) in the local catchment area of each lake investigated is the most important source of SOM in floodplain lakes of the central Amazon basin. The macrophyte community is also an important source of SOM whereas aquatic OM (i.e., riverine and lacustrine SPOM) contributes to a somewhat lesser extent. In upstream lakes, higher TOC contents in the surface sediments are observed, if compared to the downstream large open lakes. The differences observed in the vegetation coverage of the wetlands affect the quality of SOM in the floodplain lakes. This pattern could only be observed in a longitudinal transect approach, with the application of molecular isotope technique apart from multiple-biomarker analysis. The sedimentation of OM in the floodplain lakes are strongly linked to the periodic floods. The rain season (RW season), with substantially increased soil runoff, and the receding of waters (FW season), when OM is transported from the flooded soils to the floodplain lakes, are the most important hydrological factors for the sedimentation of OM in the wetlands of the central Amazon basin. Hence, together with wetland and non-flooded vegetation, the hydrodynamics of the floodplain seems to be the most important controlling factor on the composition of SOM in the floodplain lakes of the central Amazon basin.

Acknowledgements. This work was conducted in collaboration with the carbon cycle in the Amazon River (CARBAMA) project, funded by the French National Research Agency (grant no. 08-BLANC-0221) in the framework of the HYBAM Observatory (INSU/IRD). It was conducted by an international cooperation agreement between the National Council for Scientific and Technological Development - Brazil (CNPq) and the Institute for Research and Development - France (IRD) and Coordenação de Aperfeiçoamento de Pessoal de Nível Superior (CAPES). The research leading to these results has also received funding from the European Research Council (ERC) under the European Union's Seventh Framework Programme (FP7/2007-2013)/ERC grant agreement no. [226600]. We would like to thank the Companhia de Pesquisa dos Recursos Minerais (CPRM) technical groups for their help during the sampling expeditions. We also would like to thank the INCT-TMCOcean Project (CNPq Proc. 573601/2008-9) for analytical support.

Edited by: T. J. Battin

\section{References}

Abril, G., Martinez, J.-M., Artigas, L. F., Moreira-Turcq, P., Benedetti, M. F., Vidal, L., Meziane, T., Kim, J.-H., Bernardes, M. C., Savoye, N., Deborde, J., Souza, E. L., Alberic, P., Landim de Souza, M. F., and Roland, F. Amazon River carbon dioxide outgassing fueled by wetlands, Nature, 505, 395-398, 2014.

Aufdenkampe, A. K., Mayorga, E., Hedges, J. I., Llerena, C., Quay, P. D., Gudeman, J., Krusche, A. V., and Richey, J.E. Organic matter in the Peruvian headwaters of the Amazon: Compositional evolution from the Andes to the lowland Amazon mainstem, Org. Geochem., 38, 337-364, 2007.

Battin, T. J., Luyssaert, S., Kaplan, L. A., Aufdenkampe, A. K., Richter, A., and Tranvik, L. J. The boundless carbon cycle, Nat. Geosci., 2, 598-600, 2009.

Belicka, L. L. and Harvey, H. R. The sequestration of terrestrial organic carbon in Arctic Ocean sediments: A comparison of methods and implications for regional carbon budgets, Geochim. Cosmochim. Ac., 73, 6231-6248, 2009.

Bernardes, M. C., Martinelli, L. A., Krusche, A. V., Gudeman, J., Moreira, M., Victoria, R. L., Ometto, J. P. H. B., Ballester, 
M. V. R., Aufdenkampe, A. K., Richey, J. E., and Hedges, J. I.: Riverine organic matter composition as a function of land use changes, Southwest Amazon, Ecol. Appl., 14, 263-279, 2004.

Blaga, C. I., Reichart, G. J., Vissers, E. W., Lotter, A. F., Anselmetti, F. S., and Sinninghe Damsté, J. S.: Seasonal changes in glycerol dialkyl glycerol tetraether concentrations and fluxes in a perialpine lake: implications for the use of the TEX 86 and BIT proxies, Geochim. Cosmochim. Ac., 75, 6416-6428, 2011.

Bligh, E. G. and Dyer, W. J.: A Rapid Method of Total Lipid Extraction and Purification, Can. J. Biochem. Phys., 37, 911-917, 1959.

Bonnet, M. P., Barroux, G., Martinez, J. M., Syeler, F., MoreiraTurcq, P., Cochonneau, G., Melack, J. M., Boaventura, G., Maurice-Bougoin, L., León, J. G, Roux, E., Calmant, S., Kosuth, P., Guyot, J. L., and Seyler, P.: Floodplain hydrology in an Amazon floodplain lake (lago Grande de Curuai), J. Hydrol., 349, 1830, 2008.

Bourgoin, L. M., Bonnet, M. P., Martinez, J. M., Kosuth, P., Cochonneau, G., Moreira-Turcq, P., Guyot, J. L., Vauchel, P., Filizola, N., and Seyler, P.: Temporal dynamics of water and sediment exchanges between the Curuai floodplain and the Amazon River, Brazil, J. Hydrol., 335, 140-156, 2007.

Bray, E. E. and Evans, E. D.: Distribution of n-paraffins as a clue to recognition of source beds, Geochim. Cosmochim. Ac., 22, 2-15, 1961.

Buckles, L. K., Weijers, J. W. H., Tran, X.-M., Waldron, S., and Sinninghe Damsté, J. S.: Provenance of tetraether membrane lipids in a large temperate lake (Loch Lomond, UK): implications for glycerol dialkyl glycerol tetraether (GDGT)-based palaeothermometry, Biogeosciences, 11, 5539-5563, doi:10.5194/bg-115539-2014, 2014.

Callede, J., Kosuth, P., Guyot, J. L., and Guimaraes, V. S.: Discharge determination by acoustic doppler current profilers (ADCP): A moving bottom error correction method and its application on the River Amazon at Obidos, Hydrolog. Sci. J., 45, 911-924, 2000.

Castañeda, I. S., Mulitza, S., Schefu, E., Santosa, R. A. L. D., Sinninghe Damsté, J. S., and Schouten, S.: Wet phases in the Sahara/Sahel region and human migration patterns in North Africa, P. Natl. Acad. Sci. USA, 106, 20159-20163, 2009.

Cole, J. J., Prairie, Y. T., Caraco, N. F., McDowell, W. H., Tranvik, L. J., Striegl, R. G., Duarte, C. M., Kortelainen, P., Downing, J. A., Middelburg, J. J., and Melack, J.: Plumbing the Global Carbon Cycle: Integrating inland waters into the terrestrial carbon budget, Ecosystems, 10, 171-184, 2007.

De Jonge, C., Stadnitskaia, A., Hopmans, E. C., Cherkashov, G., Fedotov, A., and Sinninghe Damsté, J. S.: In situ produced branched glycerol dialkyl glycerol tetraethers in suspended perticulate matter from the Yennisei River, Eastern Siberia, Geochim. Cosmochim. Ac., 150, 476-491, 2015.

Devol, A. H., Zaret, T. M., and Forsberg, B. R.: Sedimentary organic matter diagenesis and its relation to the carbon budget of tropical Amazon floodplain lakes, Verhandlungen Internationale Vereinigung für theoretische und angewandte Limnologie 22, 1299-1304, 1984.

Ertel, J. R., Hedges, J. I., Devol, A. H., Richey, J. E., and Ribeiro, M. D. N. G.: Dissolved humic substances of the Amazon River system, Limnol. Oceanogr., 31, 139-154. 1986.
Goñi, M. A. and Hedges, J. I.: Lignin Dimers - Structures, Distribution, and Potential Geochemical Applications, Geochim. Cosmochim. Ac., 56, 4025-4043, 1992.

Goulding, M., Barthem, R., and Ferreira, E. J.: The Smithsonian Atlas of Amazon, Princeton Editorial Associates, Oklahoma City, OK, USA, 2003.

Harvey, H. R.: Sources and Cycling of Organic Matter in the Marine Water Column, in: Marine Organic Matter: Biomarkers, Isotopes and DNA, edited by: Volkman, J. K., Springer, New York, USA, 2006.

Harvey, H. R., Fallon R. D., and Patton J. S.: The effect of organic matter and oxygen on the degradation of bacterial membrane lipids in marine sediments, Geochim. Cosmochim. Ac., 50, 795804, 1986.

Hedges, J. I. and Ertel, J. R.: Characterization of Lignin by Gas Capillary Chromatography of Cupric Oxide Oxidation Products, Anal. Chem., 54, 174-178, 1982.

Hedges, J. I. and Mann, D. C.: The characterization of plant tissues by their lignin oxidation products, Geochim. Cosmochim. Acta, 43, 1803-1807, 1979.

Hedges, J. I., Clark, W. A., Quay, P. D., Richey, J. E., Devol, A. H., and Santos, U. D.: Compositions and Fluxes of Particulate Organic Material in the Amazon River, Limnol. Oceanogr., 31, 717-738, 1986.

Hedges, J. I., Cowie, G. L., Richey, J. E., Quay, P. D., Benner, R., Strom, M., and Forsberg, B. R.: Origins and processing of organic matter in the Amazon River as indicated by carbohydrates and amino acids, Limnol. Oceanogr., 39, 743-761, 1994.

Herfort, L., Schouten, S., Boon, J. P., Woltering, M., Baas, M., Weijers, J. W. H., and Damsté, J. S. S.: Characterization of Transport and Deposition of Terrestrial Organic Matter in the Southern North Sea Using the BIT Index, Limnol. Oceanogr., 51, 2196 2205, 2006.

Hess, L. L., Melack, J. M., Novo, E. M. L. M., Barbosa, C. C. F., and Gastil, M.: Dual-season mapping of wetland inundation and vegetation for the central Amazon basin, Remote Sens. Environ., 87, 404-428, 2003.

Hopmans, E. C., Schouten, S., Pancost, R. D., van der Meer, M. T. J., and Sinninghe Damsté, J. S.: Analysis of intact tetraether lipids in archaeal cell material and sediments by high performance liquid chromatography/atmospheric pressure chemical ionization mass spectrometry, Rapid Commun. Mass Sp., 14, 585-589, 2000.

Hopmans, E. C., Weijers, J. W. H., Schefu, E., Herfort, L., Sinninghe Damsté, J. S., and Schouten, S. A.: novel proxy for terrestrial organic matter in sediments based on branched and isoprenoid tetraether lipids, Earth Planet. Sci. Lett., 224, 107-116, 2004.

Huguet, C., Hopmans, E. C., Febo-Ayala, W., Thompson, D. H., Sinninghe Damsté, J. S., and Schouten, S.: An improved method to determine the absolute abundance of glycerol dibiphytanyl glycerol tetraether lipids, Org. Geochem., 37, 1036-1041, 2006.

Junk, W. J.: The Central Amazon Floodplain: Ecology of a Pulsing System, Ecological Studies, Springer, Berlin, Germany, p. 529, 1997.

Junk, W. J., Piedade, M. T. F., Parolin, P., Wittmann, F., and Schöngart, J.: Ecophysiology, Biodiversity and Sustainable Management of Central Amazonian Floodplain Forests: A Synthesis, in: Amazonian Floodplain Forests: Ecophysiology, Biodiversity 
and Sustainable Management, edited by: Junk, W. J., Piedade, M. T. F., Wittmann, F., Schöngart, J., Parolin, P., Springer, New York, USA, 511-540, 2010.

Kim, J.-H., Zell, C., Moreira-Turcq, P., Pérez, M. A. P., Abril, G. L., Mortillaro, J.-M., Weijers, J. W. H., Meziane, T., and Sinninghe Damsté, J. S.: Tracing soil organic carbon in the lower Amazon River and its tributaries using GDGT distributions and bulk organic matter properties, Geochim. Cosmochim. Ac., 90, 163$180,2012$.

Kuzyk, Z. Z. A., Goñi, M. A., Stern, G. A., and Macdonald, R. W.: Sources, pathways and sinks of particulate organic matter in Hudson Bay: Evidence from lignin distributions, Mar. Chem., 112, 215-229, 2008.

Martinelli, L. A., Victoria, R. L., Forsberg, B. R., and Richey, J. E.: Isotopic Composition of Majors Carbon Reservoirs in the Amazon Floodplain, International Journal of Ecology and environmental Sciences, 20, 31-46, 1994.

Martinelli, L. A., Victoria, R. L., Camargo, P. B. D., Piccolo, M. D. C., Mertes, L., Richey, J. E., Devol, A. H., and Forsberg, B. R.: Inland variability of carbon-nitrogen concentrations and $\delta^{13} \mathrm{C}$ in Amazon floodplain (várzea) vegetation and sediment, Hydrol. Process., 17, 1419-1430, 2003.

Melack, J. M. and Forsberg, B. R.: Biogeochemistry of Amazon Floodplain Lakes and Associated Wetlands, in: The Biogeochemistry of the amazon Basin, edited by: McClain, M. E., Victoria, F. L., and Richey, J. E., Oxford University Press, New York, USA, 235-274, 2001.

Melack, J. M. and Hess, L. L.: Remote Sensing of the Distribution and Extent of Wetlands in the Amazon Basin, in: Amazonian Floodplain Forests Ecophysiology, Biodiversity and Sustainable Management, Junk, W. J., Piedade, M. T. F., Wittmann, F., Schöngart, J., and Parolin, P., Springer, New York, USA, 511540, 2011

Meyers, P. A. Preservation of elemental and isotopic source identification of sedimentary organic matter, Chem. Geol., 114, 289302, 1994.

Moreira, L. S., Moreira Turcq, P., Kim, J.-H., Turcq, B., Cordeiro, R. C., Caquineau, S., Mandengo-Yogo, M., and Sinninghe Damsté, J. S.: A Mineralogical and Organic Geochemical Overview of the Effects of Holocene Changes in Amazon River Flow on Three Floodplain Lakes, Palaeogeogr. Palaeocl., 415, 152-164, 2014.

Moreira-Turcq, P., Jouanneau, J. M., Turcq, B., Seyler, P., Weber, O., and Guyot, J. L.: Carbon sedimentation at Lago Grande de Curuai, a floodplain lake in the low Amazon Region: insights into sedimentation rates, Palaeogeogr. Palaeocl., 214, 27-40, 2004.

Moreira-Turcq, P., Bonnet, M.-P., Amorim, M., Bernardes, M., Lagane, C., Maurice, L., Perez, M., and Seyler, P.: Seasonal variability in concentration, composition, age, and fluxes of particulate organic carbon exchanged between the floodplain and Amazon River, Global Biogeochem. Cy., 27, 119-130, 2013.

Mortillaro, J. M., Abril, G., Moreira-Turcq, P., Sobrinho, R. L., Perez, M., and Meziane, T.: Fatty acid and stable isotope $\left(\delta^{13} \mathrm{C}\right.$, $\delta^{15} \mathrm{~N}$ ) signatures of particulate organic matter in the lower Amazon River: Seasonal contrasts and connectivity between floodplain lakes and the mainstem, Org. Geochem., 42, 1159-1168, 2011

Pitcher, A., Hopmans, E. C., Shouten, S., and Sinninghe Damsté, J. S.: Separation of core and intact polar archaeal tetraether lipids using silica columms: Insights into living and fossil biomass contributions, Org. Geochem., 40, 12-19, 2009.

Quay, P. D., Wilbur, D. O., Richey, J. E., Hedges, J. I., and Devol, A. H.: Carbon Cycling in the Amazon River: Implications from the ${ }^{13} \mathrm{C}$ Compositions of Particlesand Solutes, Limnol. Oceanogr., 37, 857-871, 1992.

Raymond, P. A., Hartmann, J., Lauerwald, R., Sobek, S., McDonald, C., Hoover, M., Butman, D., Striegl, R., Mayorga, E., Humborg, C., Kortelainen, P., Dürr, H., Michel Meybeck, Ciais, P., and Guth, P. Global carbon dioxide emissions from inland waters, Nature, 503, 355-359, 2013.

Richey, J. E., Hedges, J. I., Devol, A. H., Quay, P., Victoria, R., Martinelli, L., and Forsberg, B. R.: Biogeochemistry of Carbon in the Amazon River, Limnol. Oceanogr., 32, 352-371, 1990.

Schmidt, M. W. I., Torn, M. S., Abiven, S., Dittmar T., Guggenberger G., Janssens I. A., Kleber, M., Kogel-Knabner, I., Lehmann J., Manning, D. A. C., Nannipieri P., Rasse D. P, Weiner S., and Trumbore, S. E.: Persistence of soil organic matter as an ecosystem property, Nature, 478, 49-56, 2012.

Schöngart, J., Wittmann, F., and Worbes, M.: Biomass and Net Primary Production of Central Amazonian Floodplain Forests, Amazonian Floodplain Forests Ecophysiology, Biodiversity and Sustainable Management, Springer, New York, USA, 347-388, 2010.

Schouten, S., Huguet, C., Hopmans, E. C., Kienhuis, M. V. M., and Sinninghe Damsté, J. S.: Analytical methodology for TEX 86 paleothermometry by high-performance liquid chromatography/atmospheric pressure chemical ionization-mass spectrometry, Anal. Chem., 79, 2940-2944, 2007.

Sinninghe Damsté, J. S., Shouten, S., Hopmans, E. C., van Duin, A. C. T., and Geenevasen, J. A. J.: Crenarchaeol: The characteristic core glycerol dibiphytanyl glycerol tetraether membrane lipid of cosmopolitan pelagic crenarchaeota, J. Lipid Res., 43, 1641-1651, 2002.

Sinninghe-Damsté J. S., Verschuren D., Ossebaar, J., Blokker, J., van Houten, R., van de Meer, M., Plessen, B., and Schouten, S.: A 25000 -year record of climate-induced changes in lowland vegetation of eastern equatorial Africa revealed by the stable carbonisotopic composition of fossil plant leaf waxes, Earth Planet. Sc. Lett., 302, 236-246, 2011.

Sioli, H.: Das Wasser im Amazonasgebiet, Forschung Fortschrift, 26, 274-280, 1950.

Smith, R. W., Bianchi, T .S., and Savage, C.: Comparison of lignin phenols and branched/isoprenoid tetraethers (BIT index) as indices of terrestrial organic matter in Doubtful Sound, Fiordland, New Zealand, Org. Geochem. 41, 281-290, 2010.

Tierney, J. E. and Russell, J. M.: Distributions of branched GDGTs in a tropical lake system: Implications for lacustrine application of the MBT/CBT paleoproxy, Org. Geochem., 40, 1032-1036, 2009.

Tierney, J. E., Russell, J. M., Eggermont, H., Hopmans, E. C., Verschuren, D., and Sinninghe Damsté, J. S.: Environmental controls on branched tetraether lipid distributions in tropical East African lake sediments, Geochim. Cosmochim. Ac., 74, 49024918, 2010.

Tranvik, L. J., Downing, J. A., Cotner, J. B., Loiselle, S. A., Striegl, R. J., Dillon, P., Finlay, K., Fortino, K., Knoll, L.B., Kortelainen, P.L., Kutser, T., Larsen, S., Laurion, I., Leech, D. M., McCallister, S. L., McKnight, D. M., Melack, J. M., Overholt, E., Porter, 
J. A., Prairie, Y., Renwick, W. H., Roland, F., Sherman, B. S., Schindler, D. W., Sobek, S., Tremblay, A., Vanni, M. J., Verschoor, A. M., von Wachenfeldt, E., and Weyhenmeyera, G. A.: Lakes and reservoirs as regulators of carbon cycling and climate, Limnol. Oceanogr., 54, 2298-2314, 2009.

Victoria, R. L., Martinelli, L. A., Trivelin, P. C. O., Matsui, E., Forsberg, B. R., Richey, J. E., and Devol, A. H.: The use of stable isotopes in studies of nutrient cycling: Carbon Isotope composition of Amazon varzea sediments, Biotropica, 24, 240-249, 1992.

Ward, N. D., Keil, R. G., Medeiros, P. M., Brito, D. C., Cunha, A. C., Dittmar, T., Yager, P. L., Krusche, A. V., and Richey, J. E.: Degradation of terrestrially derived macromolecules in the Amazon River, Nat. Geosci., 6, 530-533, 2013.

Weijers, J. W. H., Schouten, S., Spaargaren, O. C., and Sinninghe Damsté, J. S.: Occurrence and distribution of tetraether membrane lipids in soils: Implications for the use of the $\mathrm{TEX}_{86}$ proxy and the BIT index, Org. Geochem., 37, 1680-1693, 2006.

White, D. C., Davis, W. M., Nickels, J. S., King, J. D., and Bobbie, R. J.: Determination of the sedimentary microbial biomass by extractable lipid phosphate, Oecologia, 40, 51-62, 1979.

Zell, C., Kim, J.-H., Abril, G., Sobrinho, R. L., Dorhout, D., Moreira-Turcq, P., and Sinninghe Damsté, J. S.: Impact of seasonal hydrological variation on the distributions of tetraether lipids along the Amazon River in the central Amazon basin: implications for the MBT/CBT paleothermometer and the BIT index, Frontiers in Microbiology, 24, 1-14, 2013a.
Zell, C., Kim, J.-H., Moreira-Turcq, P., Abril, G., Hopmans, E.C., Bonnet, M.-P., Sobrinho, R .L., and Sinninghe Damsté, J. S.: Disentangling the origins of branched tetraether lipids and crenarchaeol in the lower Amazon River: Implications for GDGT-based proxies, Limnol. Oceanogr., 58, 343-353, 2013b.

Zell, C., Kim, J.-H., Dorhout, D., Baas, M., and Sinninghe Damsté, J. S.: Sources and distributions of branched tetraether lipids and crenarchaeol along the Portuguese continental margin: Implications for the BIT index, Cont. Shelf Res., 96, 34-44, 2015.

Zocatelli, R., Cecanho, F., Amorim, M., Bernardes, M., MoreiraTurcq, P., Turcq, B., Sifeddine, A., and Cordeiro, R. C.: Uso dos fenóis da lignina no estudo da matéria orgânica na Várzea do Lago Grande Curuái, Pará e no Lago do Caçó, Maranhão, Brasil, Acta Amazonica, 41, 195-204, 2011.

Zocatelli, R., Moreira-Turcq, P., Bernardes, M., Turcq, B., Cordeiro, R. C., Gago, S., Disnar, J. R., and Boussafir, M.: Sedimentary evidence of soil organic matter input to the Curuai Amazonian floodplain, Org. Geochem., 63, 40-47, 2013. 